\title{
COVID-19 HASTALIĞININ SOSYAL SİGORTALAR HUKUKU VE BİREYSEL İŞ HUKUKU AÇISINDAN İŞ KAZASI VE/VEYA MESLEK HASTALIĞI NITTELİĞİ
}

\author{
QUALIFICATION OF COVID-19 AS OCCUPATIONAL ACCIDENT AND/OR OCCUPATIONAL \\ DISEASE IN SOCIAL SECURITY AND EMPLOYMENT LAW
}

Makale Bilgi

Gönderi: 05/03/2021

Kabul : 24/05/2021

\section{Anahtar Kelimeler}

Covid-19,

Meslek Hastalı̆̆l,

iș Kazası.

Sosyal Sigorta

Ödemeleri,

İsverenin Hukuki

Sorumluluğu.

\section{Article Info}

Received: 05/03/2021 Accepted: 24/05/2021

\section{Keywords}

Covid-19,

Occupational Disease, Occupational Accident, Social Insurance Payments, Employer's Civil Liability.

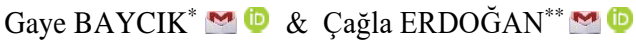

Özet

https://dai.org/I0.21492/inuhfd.891824 doi

Covid-19 hastalığının sosyal sigortalar hukuku açısından iş kazası, meslek hastalığı veya hastalık olarak nitelendirilmesi, sigortalıların haklarını etkiler. Salgın bir hastalık, sigortalının kişisel hayatında bulaşabileceği gibi çalışırken veya çalışma koşulları nedeniyle de bulaşabilir. Hastalık, iş kazasının yasal koşulları altında sigortalıya bulaştığında iş kazası olarak nitelendirilecektir. Sağlık çalışanları bakımından, Covid-19 meslek hastalığı olarak ele alınabilir. Her halde, belirlemenin yapılmasında sosyal devlet ilkesi ve sosyal sigortaların koruyucu şemsiyesinin genişletilmesi amacı dikkate alınmaldır. Yapılan iş ve çalışma koşullarından bağımsız olarak, özel hayatta hastalananlar sadece hastalık sigortasından yararlanırlar. Hastalığın bulaşma koşullarının ispatındaki güçlük, sigortalıların hak kaybına uğramasına neden olacak şekilde yorumlanmamalıdır. Bireysel iş hukuku açısından, işverenin işçiyi gözetme borcu gereği Covid-19'a karşı gelişen bilim ve teknolojinin gerektirdiği en üst düzey önlemleri alma yükümlülüğü vardır. Bu yükümlülüğün ihlali sonucunda işçinin Covid19'a yakalanması halinde işverenin tazminat sorumluluğu doğar. Filyasyon raporlarından yararlanılarak veya çalışma koşullarının değerlendirilmesi yoluyla, işçinin hastalığa yakalanması ile işverenin gözetme borcu ihlali arasında uygun illiyet bağ 1 kurulabilir. Hastalığın salgın niteliğinde olması mücbir sebep olarak nitelendirilemez ve illiyet bağını kesmez.

\begin{abstract}
The qualification of Covid-19 disease as an occupational accident, occupational disease, or sickness in terms of social insurance law affects social insurance rights. An epidemic disease can be contracted while working or due to working conditions, as well as outside work. If the disease is contracted in legal conditions that define occupational accident, then it will be considered as an occupational accident. Covid-19 can be considered as an occupational disease for healthcare professionals. When determining the legal qualification of Covid-19 for both healthcare professionals and other workers, welfare state principle and the general aim of expanding the protective umbrella of social insurances should be considered. If the insured person contracts the disease outside work, then they can only benefit from sickness insurance. Proving that the insured person contracted the disease at work or because of working conditions is a challenging task, as the virus spreads through respiratory transmission. However, difficulty in proving cannot be interpreted against the insured. In terms of employment law, the employer has the duty to protect the health and safety of the employees, and therefore must take all necessary available precautions against Covid-19. If an employee contracts the disease due to employer's failure in the duty to protect, the employer is liable for the damages. The causal connection between employee's illness and employer's breach of protection duty can be established through filiation reports or by evaluating the working conditions. The epidemic nature of the disease cannot be considered as force majeure and does not break the causal connection.
\end{abstract}

\footnotetext{
* Doç. Dr., Ankara Üniversitesi Hukuk Fakültesi, Işs ve Sosyal Güvenlik Hukuku Anabilim Dall.

${ }^{* *}$ Arş. Gör., Ankara Üniversitesi Hukuk Fakültesi, İş ve Sosyal Güvenlik Hukuku Anabilim Dalı.
} 


\section{EXTENDED SUMMARY}

The Covid-19 pandemic came along with many legal problems, one of which is the qualification of the disease as an occupational accident, occupational disease, or sickness in terms of social security law. The different possible qualifications of the Covid-19 disease in social security law, affects social insurance rights. Employer's duty to protect employees against the disease and the possible civil liability outcomes of failure in this duty constitutes brings along problems and questions in establishing the causal connection. This paper aims to discuss questions of qualification and the casual connection in employer's legal liability.

An epidemic disease can be contracted while working or due to working conditions, as well as outside work. Occupational diseases are diseases that are contracted because of the recurring characteristics of work or working conditions. Occupational diseases are listed beforehand and the diseases that do not appear in the list can be qualified as such in the legal conditions and by following the procedures prescribed by the law. Covid-19 is a pandemic and is not necessarily connected with the recurring characteristics of the work for many sectors. However, for healthcare professionals Covid-19 can be considered as an occupational disease in theory and practice. The Ministry of Health has published guidelines for qualifying Covid-19 for healthcare professionals. These guidelines do not cover all workers who work in healthcare sector and contain provisions that can hinder the qualification of Covid-19 as an occupational disease in some cases. The most suitable solution would be the inclusion of Covid-19 in the occupational diseases list for all who work in the healthcare sector, regardless their profession.

In sectors other than healthcare sector, if the Covid-19 disease is contracted in legal conditions that define occupational accident, then it will be considered as an occupational accident. The Court of Cassation has qualified the H1N1 disease and other infectious diseases as occupational accidents before. Therefore, when Covid-19 is contracted during work or because of work it can be qualified as an occupational accident. Proving that the insured person contracted the disease at work or because of working conditions is a challenging task, as the virus spreads through respiratory transmission. However, difficulty in proving cannot be interpreted against the insured. When determining the legal qualification of Covid-19, welfare state principle and the general aim of expanding the protective umbrella of social insurances should be considered. If the insured are more likely to contract the disease at work rather than outside work, then they should be awarded the occupational accident benefits. If the insured person contracts the disease outside work, then they can only benefit from sickness insurance.

In terms of employment law, the employer has the duty to protect the health and safety of the employees, and therefore must take all necessary available precautions against Covid-19. These extend of the precautions are determined by the latest developments in science and technology, therefore the employer must these precautions even if they are not prescribed by the legislation. If an employee contracts the disease due to employer's failure in the duty to protect, the employer is liable for the damages. Due to the pandemic characteristic of the disease, proving that it is contracted because of employer's breach of protection duty can be troublesome in many cases. The causal connection between employee's illness and employer's breach of protection duty can be established through filiation reports or by evaluating the working conditions. For instance, the filiation reports may directly establish that an employee has contacted the disease from another employee or the employer. However, filiation reports should not be given an absolute effect as an employee might contract the disease because of working conditions that cannot be determined in a filiation report. For instance, a supermarket cashier or a delivery person contacts many clients throughout the day and it is possible for them to contract the disease from a client without being included in their filiation reports.

The causal connection establishing the employer's liability breaks in case of employee's or third party's gross fault or in case of force majeure. The epidemic nature of the disease cannot be considered as force majeure and does not break the causal connection. However, in some cases the disease might be considered as an inevitable factor as it might be contracted even though all the available precautions are taken. In this case, the employer's legal liability should not be altogether lifted but the damages should be distributed between the employer and employee in accordance with the case law of the Court of Cassation. The distribution should not be even, and the employer should be responsible for the greatest part of the damages as set forth in the precedent cases. 


\section{GİRIŞ}

Covid-19 salgını, bu hastalığa yakalanan çalışanların ve çalışanların hastalık sonucunda ölümleri halinde yakınlarının sosyal sigorta ve tazminat haklarının neler olacağı sorularını beraberinde getirmiştir. Covid-19'un sosyal sigortalar hukuku anlamında iş kazası, meslek hastalığı veya hastalık olarak nitelendirilmesi, hem sigorta yardımlara hak kazanıldığının tespitindeki hukuki süreç hem de yardımların içeriği bakımından önemli farklar yaratmaktadır. Özellikle, hastalık sonucunda sürekli iş göremez hale gelenler ile hayatını kaybedenlerin yakınları bakımından, hukuki nitelendirmenin yarattığı sonuç arasındaki farklılıklar ciddi boyuttadır. Öte yandan hastalığa yakalandıktan sonra tamamen iyileşenler bakımından, varılacak çözümler arasında önemli farklar yoktur. Söz konusu soruların yanıtları henüz tam olarak açıklığa kavuşturulmuş değildir. 2020 yılının Mayıs ayında Sosyal Güvenlik Kurumu (SGK), Covid-19 hastalığının iş kazası veya meslek hastalığı olarak değil, hastalık sigortası kapsamında işlem göreceği yönünde bir genelge yayımlamıştır ${ }^{1}$. Daha sonra, 2020 yılının Aralık ayında Sağlık Bakanlığı, hastalığın sağlık çalışanları bakımından meslek hastalığı olarak değerlendirilmesine olanak sağlayan basında "genelge" olarak tabir edilen bir yazı yayımlamıștır ve böylece soru sağlık çalışanları bakımından kısmen yanıtlanmıştır². Bununla beraber, pandemi sürecinde hastalanan diğer çalışanların hastalıklarının işleriyle bağlantılı olup olmadığının nasıl belirleneceği ve sosyal sigorta haklarının neler olacağının açıklığa kavuşturulması gerekmektedir. Bireysel iş hukuku açısından, işverenin gerekli sağlık ve güvenlik önlemleri almaması sebebiyle hastalığa yakalanan işçiler bakımından hastalık ve iş arasında illiyet bağının kurulması ve buna bağlı olarak işverenden tazminat talep haklarının belirlenmesi önem taşımaktadır. Bu çalışmanın ilk bölümünde Covid-19 hastalığının sosyal güvenlik hukuku anlamındaki hukuki niteleği (meslek hastalığı, iş kazası, hastalık) tartışılacak; ikinci bölümündeyse işçiler bakımından hastalığın çalışma koşullarıyla illiyet bağının kurulması ve kurulabildiği takdirde işverenin tazminat sorumluluğunun belirlenmesi konusu ele alınacaktır.

\section{COVID-19 HASTALIĞININ MESLEK HASTALIĞI, İ̧̧ KAZASI VEYA HASTALIK NITTELIĞİ TARTIŞMASI}

Covid-19 hastalığına yakalanan işçiye 5510 sayılı Sosyal Sigortalar ve Genel Sağlık Sigortası Kanunu uyarınca verilecek ödeneklerin ve bağlanacak gelirlerin belirlenebilmesi için hastalığın, yasanın uygulanması bakımından hastalık mı yoksa meslek hastalığı veya iş kazası olarak mı nitelendirileceğinin tespiti gerekmektedir. Bu nitelendirme işçinin ve ölümü halinde geride kalanların hakları bakımından farklılıklar yaratmaktadır. İş kazası ve meslek hastalığı sigortasından yapılan yardımlar aynı olmakla beraber, yardımlara hak kazanma koşulları birbirinden farklılık göstermektedir. Bu bağlamda, Covid-19'un sırasıyla, meslek hastalığı, iş kazası ve hastalık tanım ve özelliklerine uygunluğu tartışılacaktır. Son kısımda, iş kazası ve meslek hastalığı sigortasından sağlanan yardımlar ve hastalık sigortasından sağlanan yardımlar karşılaştııılarak Covid-19 bağlamında bir değerlendirme yapilacaktır.

\section{A. Meslek Hastalığı}

\section{Genel Olarak}

SSGSSK m.14/1 uyarınca: "Meslek hastalı̆̆l, sigortalının çalıştığı veya yaptı̆̆g işin niteliğinden dolayı tekrarlanan bir sebeple veya işin yürütüm şsartları yüzünden uğradiğı geçici veya sürekli hastalı, bedensel veya ruhsal engellilik halleridir." Sigortalının tutulduğu hastalığın meslek hastalığ 1 sayılabilmesi için bu tanım gereği bazı unsurlar aranmaktadır. Öncelikle, sigortalının mesleki bir dış etkene maruz kalması gerekir; bu husus yasada "çalıştığ veya yaptı̆̆ işin niteliğinden dolayı tekrarlanan bir sebeple veya işin yürütüm şartları yüzünden" olarak ifade edilmektedir. Mesleki dış etken ve tekrarlanma unsurları, aşağıda da ele alınacağı üzere iş kazasının şartları arasında aranmamaktadır.Yargıtay'a göre de: "Sigortalının mesleğini icrası sırasında sürekli tekrarladı̆̆ faaliyetlerden dolayı ya da icra edilen iş̧in niteliği veya işin şartları nedeniyle mesleği ile bağlantılı olarak meydana gelen hastallklar da sosyal güvenlik sistemi içerisinde bir sosyal risk olarak kabul edilmekte ve bu hastalıklar meslek hastalığı olarak nitelendirilmektedir. İş kazası ani bir olay olmasına karşın meslek hastalı̆̆l, belirli bir zaman dilimi içerisinde tekrarlanan bir sebeple oluşmaktadır. Meslek hastalı̆̆l, işin nitelik ve yürütüm şartlarından dolayı ya da işyerinin durumu dolayısıyla yavaş yavaş ortaya çıkan bir sağlik sorunudur."

\footnotetext{
${ }^{1}$ Sosyal Güvenlik Kurumu'nun Koronavirüs (Covid-19) konulu 7.5.2020 tarihli 2020/12 say1li genelgesi.

${ }^{2}$ Sağlık Bakanlığı Yönetim Hizmetleri Genel Müdürlüğü: Covid-19 Nedeniyle Vazife Malüllüğü” konulu 18.12.2020 tarihli yazı, http://www.tdb.org.tr/tdb/ek/SB_Covid_Meslek_Hast_Genelge(Aralik.2020).pdf, Erişim Tarihi: 17.1.2021.

${ }^{3}$ SÖZER, Ali Nazım: Türk Sosyal Sigortalar Hukuku, 2. Bası, Beta Yayınları, İstanbul 2015, s.337.

${ }^{4}$ Yarg. 10. HD 15.4.2019, 2016/17217, 2019/3441, www.calismatoplum.org, Erişim Tarihi: 11.12.2020.
} 
Mesleki dış etken işin niteliğinden kaynaklanabilir. Meslek hastalıklarına hangi işlerin yol açabileceği tıbbi verilere dayanılarak önceden belirlenmiştir. Sigortalının hastalık doğuran etmene, sürekli maruz kalması gerekir; bu süre yapılan iş ve etmene göre değişmekte olup hekimler tarafından değerlendirilmektedir. Meslek hastalıkları, işin niteliğinin yanında işin yürütüm koşullarından, yani iş sağlığı ve güvenliği önlemlerin gereğince yerine getirilmemesi sebebiyle de ortaya çıkabilir. Dolayısıyla meslek hastalığında dış etken ve hastalık arasında illiyet bağ aranır $^{5}$.

Meslek hastalığının tespiti SSGSSK m.14/2 uyarınca yapılır: "Sigortalının çalıştığı işten dolayı meslek hastalı̆̆ına tutulduğunun; a) Kurumca yetkilendirilen săgllk hizmet sunucuları tarafindan usûlüne uygun olarak düzenlenen sağglk kurulu raporu ve dayanağl tıbbî belgelerin incelenmesi, $b$ ) Kurumca gerekli görüldü̈̆̈̈ hallerde, işyerindeki çalışma şartlarını ve buna bağlı tıbbî sonuçlarını ortaya koyan denetim raporlart ve gerekli diğer belgelerin incelenmesi, sonucu Kurum Sağllk Kurulu tarafindan tespit edilmesi zorunludur." Meslek hastalıkları listesi yönetmelikle belirlenmekle beraber bu liste kapalı değildir ve yönetmelikte belirlenmiş hastalıklar dışında herhangi bir hastalık yasada belirlenen koşullar altında ortaya çıkmışsa meslek hastalı̆̆ kapsamında sayılır ${ }^{6}$. Bir hastalığın Meslek Hastalıkları Listesinde yer alıp almamasının yarattığı fark; listede yer alan hastalıkların meslek hastalığı olduğunun karine olarak kabul edilmesi, buna karşllık listede yer almayan hastalıkların meslek hastalığı olduğunun sigortalı tarafından ispatının gerekmesidir ${ }^{7}$.

Sigortalılar, çalışma ortamında Covid-19'a maruz kaldığı takdirde bunun meslek hastalığı sayılıp sayılmayacağının değerlendirilmesi gerekmektedir. Meslek hastalığı tanımındaki "hastalı̆̆ın tekrarlanan ve işin kendisinden ya da koşullarından kaynaklanan sebeplerle ortaya çıkması" koşulu dikkate alındığında, Covid-19 hastalığının meslek hastalığı olarak değerlendirilmesi mümkün görünmemektedir. Yine meslek hastalığının işin niteliğinden veya yürütümünden kaynaklanan tekrarlanan veya zaman içerisinde meydana gelme özelliği de Covid-19 hastalığına uygun değildir. Hastalık işyerinde bulaşsa bile, bu salgın hastalığın kaynağı tekrarlanan iş koşulları değildir; salgının bulunmadığ bir dönemde aynı işi yapan sigortalının Covid-19 riskiyle karşılaşmayacağ 1 açıktır ${ }^{8}$. Örneğin, bir fabrikada hastalanan bir işçinin diğer işçilere hastalık bulaştırması veya bir markette çalışan işçiye müşteriden hastalık bulaşması bakımından işten kaynaklanan ve tekrarlanan bir nedenden söz etmek güçtür. Virüsün aniden bulaşması, ancak etkilerinin zamanla ortaya çıkmasının iş kazalarındaki anilik unsuruna denk geldiği değerlendirilmektedir ${ }^{9}$. Hastalığın iş kazası olarak değerlendirilmesine ilişkin tartışmaya aşağıda yer verilecektir.

\section{Sağlık Çalışanları Bakımından Meslek Hastalığı}

Sağlık çalışanlarının Covid-19 hastalığına yakalanması bakımından, hizmet akdine göre çalışanlar için meslek hastalığı ve kamu görevlisi olarak çalışanlar için vazife malullüğüne ilişkin değerlendirme ayrıca yapılmalıdır. Öğretide bir görüşe göre, günümüz koşullarında sağlık çalışanlarının hastalığa yakalanması iş kazası olarak nitelendirilmelidir; ancak zaman içinde bu değerlendirmenin değişmesi ve hastalığın meslek hastalığı olarak nitelendirilmesi mümkün olabilir ${ }^{10}$. Sosyal Sigorta Sağlık İşlemleri Tüzügü̈'nün 65. maddesine göre: "Meslek hastalıkları Listesinin D grubunda yer alan bulaşıcı hastallkların, görülen işin gereği olarak veya işyerinin özel koşullarının etkisiyle oluşmast ve enfeksiyonun laboratuvar bulgulart ile de kanitlanmast gereklidir. Meslek hastalıkları listelerinde yer almayan ve fakat görülen iş ve görev icabı olarak alındı̆̆ kesin olarak tespit edilen diğer enfeksiyon hastallkları da meslek hastallğı sayllır. Bu husustaki teşhisin laboratuvar deneyleriyle teyit edilmesi gereklidir. Hastalığın azami kuluçka süresi yükümlülük süresi olarak kabul edilir." Bu bağlamda, Covid-19 hastalığının da tüzükte yer alan koşullar altında bulaştığı ortaya konulabilirse, hastalığın meslek hastalığı olarak nitelendirilmesi mümkün olabilir.

Meslek Hastalıkları ve İşle İlgili Hastalıklar Tanı Rehberi’nde enfeksiyon hastalıkları olan SARS, tüberküloz, HIV ve Hepatit B, sağlık çalışanları bakımından halihazırda meslek hastalıkları olarak yer almaktadır. Bunlardan HIV ve Hepatit B için risk etmeni olarak, sağlık çalışanlarına iğne

\footnotetext{
${ }^{5}$ SÖZER, s.337-338

${ }^{6}$ SÖZER, s.339; GÜZEL, Ali/OKUR, Ali Rıza/CANIKLİŎLLU, Nurşen: Sosyal Güvenlik Hukuku, 18. Bası, Beta Yayınları, İstanbul 2020, s.384-388.

${ }^{7}$ TUNCAY, Can/EKMEKÇİ Ömer: Sosyal Güvenlik Hukuku Dersleri, 20. Bası, Beta Yayınları, İstanbul 2019, s.417-422.

${ }^{8}$ AKIN, Levent: “Covid-19'un İş İlişkilerine Olası Etkileri”, (Covid-19) Çimento İşveren Dergisi, 34(3), Mayıs 2020, s.20; ŞAHIN EMİR, Asiye: İşçinin Yakalandığı Bulaşıcı Hastalığın 5510 Sayılı Kanun Olup Olmadığının Değerlendirilmesi Domuz Gribi (H1N1) ve Koronavirüs (Covid-19) Özelinde Bir Değerlendirme-, Legal İSGHD 17(66), s.581.

${ }^{9}$ AKIN, Covid-19, s.22; ŞAHIN EMIR, s.581; NARTER, Sami/ŞIMIŞEK, Cebrail: "Sağlık Çalışanları İçin Covid-19 Hastalığı İş Kazası Veya Meslek Hastalığı Mıdır?”, Karatahta İş Yazıları Dergisi, (16) 2020, s.167.

${ }^{10}$ AKIN, Covid-19, s.21; Aynı yönde, ŞAHIN EMİR, s.583-584; YÜREKLİ, Sabahattin: "Çalışma Hayatında Koronavirüs (Covid-19) Salgınının Etkileri, İstanbul Ticaret Üniversitesi Sosyal Bilimler Dergisi Covid-19 Hukuk Özel Sayısı”, 19(38), s.45.
} 
veya sivri uçlu cisim batması gösterilmiştir ${ }^{11}$. Söz konusu hastalıklardan SARS, geçmişte salgın yaratmıştır ve Covid-19 gibi solunum yoluyla bulaşmaktadır ${ }^{12}$. SARS'ın listeye alınmış olması Covid19'un de meslek hastalıkları listesine alınması için örnek teşkil edebilecek niteliktedir.

Covid-19'un solunum yoluyla bulaşması, sağlık çalışanlarının hastalığı işyeri dışında kapma ihtimalini barındırmakla beraber bu kişilerin hastalığı işyerinde kapma ihtimalleri daha yüksektir. 2020 Aralık ayında, enfekte olan 1 milyon 900 bin kişiden 120 bininin sağ lik çalışanı olduğu ifade edilmiştir; bu enfekte olan her 15 kişiden birinin sağlık çalışanı olduğu anlamına gelmektedir. Aynı zamanda hastalanan her 10 kişiden birinin sağlık çalışanı olduğu ifade belirtilmiştir ${ }^{13}$. Sağlık çalışanlarının sayısının $(1.061 .635)^{14}$ toplam nüfus $(83.154 .997)^{15}$ ve toplam çalışan nüfus $(31.542 .000)^{16}$ içindeki oranının \%10'dan çok daha düşük olduğu dikkate alındığında sağlık çalışanlarının işleri ve enfeksiyon oranları arasında bir bağlantı kurulabileceği açıktır. Covid-19'un meslek hastalığı olarak değerlendirilebilmesi bakımından dikkate alınabilecek bir diğer husus, enfeksiyon hastalıklarında vücuda giren patojenlerin dozunun hastalanmaya ve hastalığın seyrine etki edebileceğidir ${ }^{17}$. Covid-19 hastalığı bakımından kesin sonuçlara varılmamış olsa da viral yük olarak ifade edilen, vücuda giren virüs sayısı hastalanmayı ve hastalığın seyrini etkileyebilmektedir. Teorik olarak sağlık çalışanlarının, zaman içerisinde daha yüksek doz virüse maruz kalması mümkündür ${ }^{18}$. Sağlık çalışanlarının kişisel koruyucu donanım kullandığı ancak bunların virüsü tamamen önleyemediği dikkate alındığında, sağlık çalışanının hasta eden virüs dozunu zaman içerisinde alma ihtimali vardır. Bu halde, sigortalının hastalığı iş kazasındaki anilik unsurundan uzaklaşarak meslek hastalı̆̆ının zaman içerisinde gerçekleşme özelliğine uygun olarak ortaya çıkabilir.

SSGSSK' deki kısa vadeli sigorta kolları kamu görevlileri bakımından uygulama bulmaz (m.4/6). Kamu görevlileri geçici iş göremezlikleri halinde 657 sayılı Devlet Memurları Kanunu uyarınca aylıklarını tam olarak alırlar. Kamu görevlileri, iş kazası ve meslek hastalıkları sigortası yerine SSGSSK m.47'de düzenlenen vazife malullüğü sigortasından yararlanırlar. Bu sigortadan sağlanan edim, en az \%60 çalışma gücü kaybının olması halinde, vazife malullüğü aylığıdır. 47. maddeye göre: "malûllük; sigortalıların vazifelerini yaptıkları sırada veya vazifeleri dışında idarelerince görevlendirildikleri herhangi bir kamu idaresine ait başka işleri yaparken bu işlerden veya kurumlarının menfaatini korumak maksadıyla bir iş yaparken ya da idarelerince sağlanan bir taşıtla işe gelişi ve işten dönüşü sırasında veya işyerinde meydana gelen kazadan doğmuş olursa, buna vazife malûllüğü ve bunlara uğrayanlara da vazife malûlü denir." Bu düzenlemede kamu görevlilerinin vazife hastalıkları yer almamakla ve bir meslek hastalıkları listesi bulunmamakla beraber, vazife malullüğü meslek hastalıklarından doğabilir ${ }^{19}$. Kamu görevlisi sağlık çalışanlarının Covid-19 hastalığına yakalanmaları halinde, hastalığın vazife hastalığı olarak veya vazife kazası olarak da nitelendirilmesi uygulanacak hükümde değişiklik yaratmamaktadır, her halde SSGSSK m.47 uygulama bulacaktır.

Sağlık çalışanlarının Covid-19 hastalığına yakalanmalarının iş kazası mı yoksa meslek hastalığı mı oluşturduğu tartışması teorik olarak sürdürülebilirse de, Sağlık Bakanlığı'nın 18.12.2020 tarihli yazısı, bu tartı̧̧mayı uygulamada sona erdirecek niteliktedir. Söz konusu yazıya göre, Covid-19 tanısı alan sağlık çalışanları hastalıkları sebebiyle meslekte kazanma gücü veya çalışma gücü kaybına uğramışlarsa illiyet bağının kurulması şartıyla meslek hastalığı ve vazife malullüğü kapsamındaki

11 ÇSGB: "Meslek Hastalıkları ve İşle İlgili Hastalıklar Tanı Rehberi”, https://www.ailevecalisma.gov.tr/medias/4597/rehber20.pdf, Erişim Tarihi: 17.1.2020, s. 330.

12 WHO: "Severe Acute Respiratory Syndrome (SARS)", https://www.who.int/health-topics/severe-acute-respiratorysyndrome, Erişim Tarihi: 17.1.2020

13 Deutsche Welle Türkçe: "Türkiye'de her 10 koronavirüs hastasından 1'i sağlı çalışanı" https://www.dw.com/tr/türkiyede-her-10-koronavirüs-hastasından-1i-sağlık-çalışanı/a-56000410, Erişim Tarihi: 5.1.2020. 14 T.C. Sağlık Bakanlığı: "Bakan Koca, Koronavirüse İlişkin Son Durumu Değerlendirdi" https://www.saglik.gov.tr/TR,65032/bakan-koca-koronaviruse-iliskin-son-durumu-degerlendirdi.html, Erişim Tarihi: 5.1.2020.

15 TÜİK: “Adrese Dayalı Nüfus Kayıt Sistemi Sonuçları, 2019”, https://data.tuik.gov.tr/Bulten/Index?p=Adrese-DayaliNufus-Kayit-Sistemi-Sonuclari-2019-33705, Erişim Tarihi: 5.1.2020.

16 TÜIK: “İşgücü İstatistikleri, Ekim 2020" https://data.tuik.gov.tr/Bulten/Index?p=Isgucu-Istatistikleri-Ekim-202037485\&dil=1, Erişim Tarihi: 5.1.2020.

${ }^{17}$ BAKIRCI, Çağrı Mert: "Enfeksiyon Dozu (ID50) ve Ölümcül Doz (LD50) Nedir? Hasta Olmak İçin Kaç Tane Virüs Bulaşmalı?" https://evrimagaci.org/enfeksiyon-dozu-id50-ve-olumcul-doz-ld50-nedir-hasta-olmak-icin-kac-tane-virusbulasmali-8243, Erişim Tarihi: 17.7.2020.

18 CADDY, Sarah L: "Does The Amount of Coronavirus You're Exposed to Determine How Sick You'll Get?" https://www.sciencealert.com/does-the-amount-of-covid-19-virus-you-are-exposed-to-determine-how-sick-you-ll-get, Erişim Tarihi: 17.7.2020.

${ }^{19}$ SÖZER, s.287, 290. 
sosyal güvenlik haklarından yararlanabilirler. Sağlık çalışanın hayatını kaybetmesi halinde ise, geride kalan yakınları ilgili sigorta kollarından hak sağlanan edimlere hak kazabilirler. Bu haklardan yararlanma talebinde bulunabilmek için, yazı ekinde yer alan formun doldurulması gerekmektedir ${ }^{20}$. Covid-19'un meslek hastalığı veya vazife malullüğü olarak işlem görmesini sağlayacak bu yazı bakımından tartışılması gereken hususlar, yazının kapsamındaki kurum ve kuruluşlar ile sağlık çalışanı olarak nitelendirilenlerin kimler olduğu ve yazı ekindeki formun illiyet bağı kurulmasını güçleştirebilecek içeriğidir.

Sağlık Bakanlığı yazısında, bakanlığa bağlı ve üniversitelere bağlı sağlık kurum ve kuruluşları ile özel sağlık kurum ve kuruluşlarında başvuruda izlenecek yöntem yer almaktadır. Özel sağlık kurum ve kuruluşu tanımı kapsamına, özel hastanelerin yanında Ayakta Teşhis ve Tedavi Yapılan Özel Sağlık Kuruluşları Hakkında Yönetmelik m.2 uyarınca, "tıp merkezleri, poliklinikler, laboratuvarlar, müesseseler ve muayenehaneler"'in de girdiği ve Ağız ve Diş Sağlığı Hizmeti Sunulan Özel Sağlık Kuruluşları Hakkında Yönetmelik m.2 uyarınca "diş hekimlerinin mesleklerini serbest olarak icra etmek üzere münferiden ve müştereken açtıkları ağız ve diş sağlığ hizmeti verilen muayenehane ve özel ağız ve diş sağlığı poliklinikleri ile merkezleri"nin girdiği sonucuna varmak gerekmektedir. Ayrıca, Sağlık Bakanlığı'nın 2019/10 Sağlık Hizmeti Sunucularının Basamaklandırılması Hakkında Genelgesi uyarınca, örneğin eczaneler ve işyeri sağlık ve güvenlik hizmeti sunulan birimler birinci basamak sağlik kuruluşu sayılmaktadır ${ }^{21}$.

Sağlık kurum ve kuruluşlarında çalışanların tamamı sağlık çalışanı sayılmamaktadır. Sağlık Meslek Mensupları ile Sağlık Hizmetlerinde Çalışan Diğer Meslek Mensuplarının İş ve Görev Tanımlarına Dair Yönetmelik kimlerin sağlık çalışanı sayıldığının tespitinde yol göstericidir. Bu yönetmeliğe göre sağlık meslek mensupları, hekimler, diş hekimleri, eczacılar, ebe hemşire, klinik psikologların yanında yönetmelik ekinde (Ek-1) sıralanan kişilerdir ${ }^{22}$. Sağlık hizmetlerinde çalışan diğer meslek mensupları da yönetmelik ekinde sayılmıştır (Ek-2) ${ }^{23}$. Dolayısıyla, sağlık kurum ve kuruluşlarında çalışan ve bu nedenle hastalarla temas eden çalışanların tamamı sağlık hizmetlerinde çalışan diğer meslek mensubu sayılmamaktadır. Yönetmelikte sayılan kişilerin yanında, temizlik işçisi, ambülans şoförü, veznedar, hastanedeki danışma personeli gibi hastalık tanı ve tedavisinde doğrudan rol almamakla beraber işi gereği hastalarla temas eden çalışanlar da risk altındadır. Ayrıca, hastalarla temas etmeseler dahi, örneğin hastane arşiv birimi, teknik servis çalışanı gibi kişiler hastalığa yakalanma riski olan sağlık çalışanlarıyla olan temaslarından dolayı risk altındadır. Bu nedenlerle, yaptığ işin ne olduğuna bakılmaksızın, sağlık kurum ve kuruluşunda çalışan herkesi kapsayan açık bir düzenleme getirilmesi kanımızca daha uygun olurdu.

Sağlık Bakanlığı'nın meslek hastalığı ve vazife malullügüne dair yazısının ekinde, sağlık çalışanın görev yaptığı birimde Covid-19 hasta takip ve tedavisi yapılıp yapılmadığı (1) ve ilgilinin çalıştı̆̆ birimde görev yapan diğer personelde Covid-19 tanısı alan kişi olup olmadığ 1 (2) sorulmaktadır. Bu soruların yanıtlarına meslek hastalığı ve vazife malullüğü tespitinde etkisinin ne olacağı henüz açık değilse de bunlara mutlak bir etki tanınması ve her iki soruya da kümülatif olarak "evet" yanıtının aranması haksız sonuçlar doğurabilir. Örneğin, bir işyeri hekiminin çalıştığı fabrikada işçilerin Covid-19'a yakalanması durumunda birinci sorunun yanıtı hayır ikincinin evet olacaktır. Bir başka örnek vermek gerekirse, Covid-19 tanı ve tedavisi yapılan bir hastanede tek bir hekimin hastalanması durumunda ilk sorunun yanıtı evet, ikincininki hayır olacaktır. Yine özel bir muayenehanede her iki sorunun da yanıtı hayır olduğu halde bir hekimin hastasından Covid-19 kapmas1 mümkündür. Kanımızca, bu tür bir uygulama yerine Covid-19'un sağlık kurum ve

\footnotetext{
${ }^{20}$ Sağlık Bakanlığı Yönetim Hizmetleri Genel Müdürlüğü: Covid-19 Nedeniyle Vazife Malüllüğ̈̈” konulu 18.12.2020 tarihli yazı, http://www.tdb.org.tr/tdb/ek/SB_Covid_Meslek_Hast_Genelge(Aralik.2020).pdf, Erişim Tarihi: 17.1.2021.

${ }_{21}$ T.C. Sağlık Bakanlığı'nın Sağlık Hizmetlerinin Basamaklandırılması Konulu 31.5.2019 tarih ve 2019/10 sayılı Genelgesi.

22 Söz konusu meslekler Ek-1'de sıralanmaktadır: fizyoterapist, fizyoterapi teknikeri, odyolog, odyometri teknikeri, diyetisyen, dil ve konuşma terapisti, podolog, sağlık fizikçisi, radyoterapi teknikeri, anestezi teknisyeni/teknikeri, tıbbi laboratuvar teknisyeni, tıbbi laboratuvar ve patoloji teknikeri, tıbbi görüntüleme teknisyeni/teknikeri, ağız ve diş sağlı̆̆ teknikeri, diş protez teknikeri tıbbi protez ve ortez teknisyeni/tekniker, ameliyathane teknikeri, adli tıp teknikeri, diyaliz teknikeri, perfüzyonist, eczane teknikeri iş ve uğraşı terapisti (ergoterapist), iş ve uğraşı teknikeri (ergoterapi teknikeri), elektronörofizyoloji teknikeri, mamografi teknikeri, optisyen, acil tıp teknikeri, acil tıp teknisyeni, hemşire yardımcısı, ebe yardımcısı, sağlık bakım teknisyeni.

${ }^{23}$ Söz konusu meslekler Ek-2'de sıralanmaktadır: psikolog, biyolog, çocuk gelişimcisi, sosyal çalışmacı/sosyal hizmet uzmanı, sağlı eğitimcisi, tıbbi teknolog, sağlık idarecisi, çevre sağlığı teknisyeni/tekniker, yaşlı bakım teknikeri, evde hasta bakım teknikeri, tıbbi sekreter, biyomedikal cihaz teknikeri.
} 
kuruluşlarında çalışan herkes bakımından meslek hastalıkları listesine alınması daha adil ve kapsayıcı bir çözüm oluşturur.

\section{B. İs Kazası}

İş kazası SSGSSK m.13/1'de tanımlanmaktadır. Buna göre "İş kazası; a) Sigortalının işyerinde bulunduğu sırada, b)Işveren tarafindan yürütülmekte olan iş nedeniyle sigortalı kendi adına ve hesabina bağımsı çalışıyorsa yürütmekte olduğu iş nedeniyle, c) Bir işverene bağlı olarak çalışan sigortalının, görevli olarak işyeri dışında başka bir yere gönderilmesi nedeniyle asıl işini yapmaksızın geçen zamanlarda, d) Bu Kanunun 4 üncü maddesinin birinci fikrasının (a) bendi kapsamindaki emziren kadın sigortalının, iş mevzuatı gereğince çocuğuna süt vermek için ayrılan zamanlarda, e) Sigortalıların, işverence săğlanan bir taşıtla işsin yapıldı̆̆ yere gidiş gelişi sırasında, meydana gelen ve sigortaliyı hemen veya sonradan bedenen ya da ruhen engelli hâle getiren olaydır. "Yasa anlamında iş kazasının unsurları, kazaya uğrayanın 5510 sayılı kanun anlamında sigortalı sayılması, sigortalının kazaya uğraması, sigortalının kaza sonucu bedensel veya ruhsal bir zarara uğraması ve kaza ile sigortalının uğradığı zarar arasında illiyet bağının bulunmasıdır ${ }^{24}$.

Bir kazanın sosyal güvenlik hukuku anlamında iş kazası sayılması ve sigortalıların sigorta yardımlarına hak kazanmaları için kaza ile ortaya çıkan zarar arasında uygun illiyet bağının bulunması gerekir ${ }^{25}$. Buna karșllık, işverenin tazminat sorumluluğunu doğuran iş kazasından farklı olarak, (SSGSSK m.13/1'de iș kazası sayılan hallerden b bendi dışında) kazanın yapılan işle uygun illiyet bağ içerisinde olması aranmaz. Yargitay Hukuk Genel Kurulu bu hususu şu şekilde ifade etmiştir: "Yasanın iş kazasını sigortaliyı zarara uğratan olay biçiminde nitelendirmişs olması illiyet (nedensellik) bă̆ını iş kazasinın bir unsuru olarak ele almayl gerektirmişstir. Ne var ki, burada aranan 'uygun illiyet (nedensellik) bağı' olup, bu da yasanın aradığ l hal ve durumlardan herhangi birinde gerçekleșme olgusu ile sonucun birbiriyle örtüşmesi olarak anlaşılmalı, yasada olmadığı halde, herhangi başkaca kısıtlayıcı bir koşulun varlı̆̆ aranmamalıdır. Kısacası; anılan yasal düzenleme, Sosyal Güvenlik Hukuku ilkeleri içinde değerlendirilmeli; maddede yer alan herhangi bir hale uygunluk varsa zararlandırıcı sigorta olayının kaynağının işçi olup olmaması ya da ortaya çıkmasındaki diğer etkenlerin değerlendirilmesinde dar bir yoruma gidilmemelidir." ${ }^{\text {"26 }}$ Dolayısıyla m.13/1'de yer alan hallerden biri içerisinde kazaya uğrayan sigortalı, kaza yaptığı işle uygun illiyet bağı bulunmasa bile sosyal sigorta yardımlarına hak kazanacaktır. İş kazası kavramının yasada bu şekilde geniş düzenlenmesindeki amaç, sosyal güvenlik hakkının koruyucu kapsamının mümkün olduğunca tutulmasidir ${ }^{27}$.

SSGSSK'nın m.13'te yer alan karinelere içerisinde uğranılan kazanın, bir hastalık kapma şeklinde ortaya çıkmasını mümkündür. Kazaya uğrama, sigortalının bedensel ya da ruhsal zarara uğramasını veya ölmesini ifade eder. Zararın dıșsal bir etkiden kaynaklanması ve aniden veya kısa bir süre içerisinde gerçekleşmesi gerekir ${ }^{28}$. Meslek hastalığından farklı olarak, sigortalının işten kaynaklanan tekrarlanan nedenlere dayanmayan bir bulaşıcı hastalığa işi nedeniyle yakalanması iş kazası olarak nitelendirilir ${ }^{29}$. Örneğin Fransız hukukunda sigortalının işveren tarafindan zorunlu olarak uygulanan Hepatit C aşısı sebebiyle MS (Multipl Skleroz) hastalığına yakalanması, HIV ile kontamine bir iğnenin sigortalının eline batması, görevi gereği Afrika'ya giden sigortalının sivrisinek sokması sebebiyle sıtma atağı geçirmesi iş kazası sayılmıştır ${ }^{30}$. Yargıtay da, sigortalının işyerinde tetanos mikrobu olarak ölmesini ${ }^{31}$ ve bir tarım işçisinin çalışırken kene 1sırması sebebiyle Kırım Kongo

\footnotetext{
${ }^{24}$ GÜZEL/OKUR/CANIKLİĞLU, s.358-377; SÖZER, s.310-333; AKIN, Levent: İş Kazasından Doğan Maddi Tazminat, Yetkin Yayınları, Ankara 2001, s.42-43.

${ }^{25}$ GÜZEL/OKUR/CANIKLİOĞLU, s.375-377; SÖZER, s.332-333; AKIN, s.39; SÜZEK, Sarper: İş Hukuku, 19. Bas1, Beta Yayınları, İstanbul 2020, s.422-424; SERATLI, Gaye Burcu: İş Kazasından Doğan Destekten Yoksun Kalma Tazminatı, Yetkin yayınları, Ankara 2003, s.33.

${ }^{26}$ Yarg. HGK. 14.10.2009, 21-400/432 (www.turkhukuksitesi.com). Yargitay'ın işle uygun illiyet bağı içinde olmamakla beraber yasada yer alan karinelerde gerçekleşen, öldürme olayların, silahlı ve bombalı saldırıda, trafik ve uçak kazasındaki ölümleri iş kazası olarak değerlendirmiştir, ERDOĞAN, Çağla: İşveren ve İşveren Vekilinin İş Kazasından Doğan Cezai Sorumluluğu, Yetkin Yayınları, Ankara 2016, s.64-65, dn. 152-157.

${ }^{27}$ SÜZEK, s.424; ÖZDEMIR, Erdem: İş Sağlığı ve Güvenliği Hukuku, Vedat Kitapç1lık İstanbul 2014, s.513; İş kazasının belirlenmesinde sigortalının işverenin otoritersi altında olup olmadığını önem taşıdığı yönünde bkz. TUNCAY/EKMEKÇİ, s.394-397.

${ }^{28}$ GÜZEL/OKUR/CANIKLİOĞLU, s.374-375.

${ }^{29}$ SÖZER, Ali Nazım: “Sosyal Sigortaların Genel Hükümleri ve Türleri”, Yargıtay'ın İş Hukuku ve Sosyal Güvenlik Hukuku Kararlarının Değerlendirilmesi Semineri 2014, Oniki Levha Yayınları, İstanbul 2017, s.458.

${ }^{30}$ Söz konusu Fransız Yargitayı kararları sirasıyla, Cass. soc., 2 avr. 2003, no 00-21.768, Cass. 2e civ., 17 déc. 2009, no 08-21.598Cass. soc., 17 Jan 1991, no 89-13.703 aktaran FRANGIÉ-MOUKANAS, Joumana - POTIER, Corinne: Coronavirus : un risque professionnel ?, Semaine Sociale Lamy, No. 1909, 25.5.2020. (https://www.lamyline.fr), s.3-4/7.

${ }^{31}$ Yarg. 10. HD. 4.6.1974, 3244/3890, aktaran ŞAHIN EMIR, s.568.
} 
kanamalı ateşi hastalığına yakalanarak ölmesini iş kazası saymıştır ${ }^{32}$. Söz konusu örneklerde, aşılama, iğne batması, kene 1sırması gibi hastalığın sebebini oluşturan olgunun kesin olarak tespit edilmesi, olayın iş kazası olduğunun belirlenmesinde şüpheye yer bırakmamaktadır. Ancak Covid-19 ve solunum yoluyla bulaşan diğer hastalıklar bakımından hastalığın 13. maddede yer alan karineler içerisinde kapıldığının tespiti güçlükler barındırmaktadır.

Yargıtay 21. Hukuk Dairesi, daha önce bir sigortalının solunum yoluyla bulaşan bir hastalık olan H1N1 (domuz gribi) hastalığına yakalanmasını sosyal güvenlik hukuku anlamında iş kazası olarak değerlendirmiştir: "Somut olayda, tır şoförü olan davacı murisinin 26.11.2009 tarihinde davalı işveren tarafindan Ukrayna'ya sefere gönderildiği,11.12.2009 tarihinde Türkiye'ye giriş yaptığl, Adli Tip Kurumu raporunda, H1N1 virüsünün kuluçka süresinin 1-4 gün arasında değiştiği, murisin 13.12.2009 tarihli hastaneye başvurusunda belirttiği şikayetlerin hastalı̆̆ı başlangıç belirtileri olduğu taktirde hastalı̆̆ın bulaşmasının bu tarihten 1-4 gün öncesinde gerçekleşmiş olacağının bildirildiği, buna göre davacı murisinin, işveren tarafindan yürütülmekte olan iş nedeniyle Ukrayna'ya yapılan sefer sirasında bulaştığ yukarıda belirtilen rapor kapsamından anlaşılan HIN1 virüsüne bağlı olarak, daha sonra meydana gelen ölümünün iş kazası olarak kabul edilmesi gerektiği açıktır." ${ }^{33}$ Yargitay 21. Hukuk Dairesi'nin kararındaki temel husus, H1N1 virüsünün kuluçka süresinin 1-4 gün olmasıdır. H1N1 virüsünün kuluçka süresinin kısa olmasıyla, muris işçinin söz konusu virüsü, işi nedeniyle seferde olduğu dönemde kaptığı açıç̧a ortaya konmuştur. Bu noktadan hareket eden Yüksek Mahkeme, işçinin işi nedeniyle seferde olduğu sırada virüsü almasını, iş nedeniyle uğranılan kaza olarak nitelendirmiş ve iş kazası tespitini 5510 sayılı Kanunun 13/1-b bendine göre yapmıştır.

Covid-19'un kuluçka süresinin H1N1 virüsüne göre daha uzun olduğu, genellikle 5-6 gün olmakla beraber, 2-14 gün arasında değiştiği bilinmektedir ${ }^{34}$. 5510 sayılı Kanunun 13/1-(a), (b) veya (c) bendinde yer alan karineler uyarınca iş kazası tespiti yapılabilmesi için, sigortalının virüsü işyerinde, yürüttüğü iş nedeniyle veya gönderildiği yerde kaptığının ispat edilmesi gerekir, ancak bunun ispatı kuluçka süresinin daha uzun olması sebebiyle daha güç olacaktır ${ }^{35}$. Ne var ki, Covid-19'un yasada yer alan karineler içerisinde kapıldığının ispat edilebileceği haller de söz konusu olabilir; örneğin, tır şöforlerinin veya gemiadamlarının 14 günden uzun süren seferlerde hastalanmaları veya sigortalının 14 gün ve daha uzun süren bir iş seyahati sırasında hastalanması gibi hallerde ispat sorun oluşturmayacaktır. Sigortalının işyerinde veya işverenin hanesinde yatılı olarak kaldığı durumlarda ispat güçlüğü yoktur. Ayrıca, işverenin tazminat sorumluluğu incelenirken aşağıda ayrıntılı olarak açıklanacağı üzere, sigortalının çalışma arkadaşları veya müşteriler arasında Covid-19 hastalığı kapanların bulunması veya işi gereği çok sayıda üçüncü kişiyle muhatap olan sigortalının (markette kasiyer, kurye gibi) kendi sosyal çevresinde hiç pozitif vaka bulunmaması gibi hallerde, hastalığın yasadaki karinelere uygun olarak işyerinde veya işle ilgili olarak bulaştığ 1 ve dolayısıyla iş kazası oluşturduğu sonucuna varılabilir. ${ }^{36}$

\section{Hastalık}

SSGSSK m.15'e göre: “4. maddenin birinci fikrasinin (a) ve (b) bentleri kapsamindaki sigortalının, iş kazası ve meslek hastalı̆̆ dışında kalan ve iş göremezliğine neden olan rahatsızlıklar, hastalık halidir." Dolayısıyla rahatsızlığın yasa anlamında hastalık niteliği taşıması ve hastalık sigortasından sağlanan edimlere hak kazandırabilmesi için iş kazası veya meslek hastalığ niteliği taşımaması gerekir. Hastalık sigortasından sigortaya sağlanan tek edim, geçici iş göremezlik ödeneğidir. Hastalığın tedavisi için sağlanacak sağlık hizmetleri genel sağlık sigortası kapsamında sunulur ${ }^{37}$.

Sigortalının Covid-19'a maruz kalarak hastalanması, yukarıda ele alındığı üzere yasanın 13 . maddesinde yer alan karinelere uygun olarak gerçekleşmiş olabileceği gibi, sigortalının özel yaşamından da kaynaklanmış olabilir. Yasanın 13. maddesindeki koşulların var olmadığı halde sigortalı, hastalık sigortasından yararlanarak iş göremezliğinin üçüncü gününden itibaren geçici iş göremezlik ödeneğinden yararlanabilir. Öte yandan Sosyal Güvenlik Kurumu, Covid-19 hastalığının,

\footnotetext{
32 Yarg. 21. HD. 13.05.2014, 6372/10626, www.yargitay.gov.tr, Erişim Tarihi: 7.7.2020.

${ }^{33}$ Yarg. 21. HD. 15.04.2019, 2018/5018, 2019/2931, www.calismatoplum.org, Erişim Tarihi: 10.7.2020.

${ }^{34}$ T.C. Sağlık Bakanlığı, “COVID-19 Bilgilendirme Sayfası”, https://covid19bilgi.saglik.gov.tr/tr/sss/halka-yonelik.html, 2.1.2021. WHO: "Transmission of SARS-CoV-2: implications for infection prevention precautions

Scientific Brief", https://www.who.int/news-room/commentaries/detail/transmission-of-sars-cov-2-implications-forinfection-prevention-precautions, Erişim Tarihi: 2.1.2021.

${ }^{35}$ AKIN, Covid-19, s.24.

${ }^{36}$ ŞAHIN EMIR, s.577-579; ARSLAN DURMUŞ, Seda: “COVID-19'un İş Kazası ve Meslek Hastalığı Bakımından Değerlendirilmesi”, İstanbul Hukuk Mecmuası, 78(2), 2020, s.377.

${ }^{37}$ SÖZER, s.223-224; GÜZEL/OKUR/CANIKLİĞLU, s.440.
} 
SSGSSK anlamında "hastalık" olarak işlem görmesine yönelik bir genelge yayımlamıştır. 2020/12 sayılı genelgeye göre: "Covid-19 virüsünün bulaşıcı bir hastalık olduğu dikkate alındı̆ğnda, söz konusu salgına maruz kalan ve sağllk hizmet sunucularına müracaat eden sigortalılara hastalık kapsamında provizyon alınması gerekmektedir. " ${ }^{38}$ Yukarıda açıklandığı üzere sigortalının Covid-19 hastalığına maruz kalması yasanın 13. maddesinde yer alan karinelere uygun olarak gerçekleşmişse, hastalık iş kazası olarak değerlendirilmelidir ${ }^{39}$. Dolayısıyla, bu ayrıma gidilmeksizin Covid-19'a yakalanan hastaların tamamına hastalık sigortasının uygulanması ve bunun sonucunda iş kazası ve meslek hastalıkları sigortasından sağlanan edimlerden yararlandırılmamalarına ilişkin genelge yasaya aykırıdır. Sigortalının Covid-19 hastalı̆̆ına ne şekilde yakalandığının tespitindeki güçlük ve bu hastalığın bir salgın olması sigortalıların iş kazası ve meslek hastalığı sigortasından yararlandırılmamalarının gerekçesini oluşturamaz. Kaldı ki, yukarıda ifade edildiği üzere, sigortalının hastalığa maruziyetinin yasanın 13. maddesinde yer alan karineler içerisinde gerçekleştiğinin ispatlanabileceği pek çok hal vardır. Yasanın 15. maddesinde yer alan tanıma uygun olarak, iş kazası ve meslek hastalığı olarak nitelendirilemeyecek koşullarda Covid-19 hastalığına yakalananlar bakımından hastalık sigortası hükümleri uygulanmalıdır.

Sigortalı hastalık sonucunda malul olmuşsa, uzun vadeli sigorta kollarından maluliyet aylığı bağlanabilir. SSGSSK m.25/1'e göre malul sayılmak için çalışma gücünün en az \%60 oranında yitirilmiş olması gerekir. Burada, çalışma gücü kaybının sebebi sınırlandırılmış değildir; iş göremezlik herhangi bir nedenle ortaya çıkabilir.

\section{Değerlendirme}

Sosyal güvenlik uygulamasında Covid-19 hastalığının, iş kazası veya meslek hastalığı olarak işlem görmesi ile hastalık olarak işlem görmesinde hem edimlerden yararlanma koşulları hem de sunulan edimler bakımından farklılıklar vardır.

Hastalık sigortasından sağlanan tek edim, geçici iş göremezlik ödeneğidir. Hastalık sigortasında geçici işgöremezlik ödeneği, işgöremezliğin üçüncü gününden itibaren bağlanır; yani iş göremezliğin iki günden fazla sürmesi gerekir (m.18/1-b). İş kazası ve meslek hastalığından geçici iş göremezlik ödeneği ilk günden itibaren ödenir (m.18/1-a). Ayrıca geçici iş göremezlik ödeneğinden yararlanabilmek için, sigortalı adına iş göremezliğin başladığı tarihten önceki bir yıl içinde en az doksan gün kısa vadeli sigorta primi bildirilmiş olması gerekir (m.18/1-b). İş kazası ve meslek hastalığ sigortasından ödenen gelir ve ödenekler bakımından bu tür bir koşul bulunmamaktadır. İlk bakışta, Covid-19 hastalığının değerlendirilmesindeki farklılık sadece iki günlük geçici iş göremezlik ödeneği farkı ve edimlerden yararlanmaktaki prim koşulları olarak görülebilirse de, esas farklılık sigortalının sürekli iş göremezliğe uğraması veya ölümü halinde ortaya çıkmaktadır.

Hastalık sigortasında sürekli iş göremezlik geliri ve işçinin ölümü halinde geride kalanlara gelir bağlanması söz konusu değildir. Buna karşılık iş kazası ve meslek hastalığı sigortasında, en az \%10 oranında meslekte kazanma gücü kaybı yaşayan sigortalıya sürekli iş göremezlik geliri bağlanır ve sigortalının ölümü halinde hak sahiplerine ölüm geliri bağlanır (m.19-20). Dolayısıyla sürekli iş göremezlik ve ölüm halinde, gerçekte iş kazası veya meslek hastalığı olarak nitelendirilebilecek bir vakanın hastalık olarak işlem görmesinde ciddi bir hak kaybı ortaya çıkmaktadır.

ILO Uzmanlar Komitesi'ne göre, kişi yaptığı işle bağlantılı olarak Covid-19 hastalığına yakalanmışsa, bunun işle bağlantılı bir zarar (employment injury), yani duruma göre iş kazası veya meslek hastalığı olarak tanınması gerekmektedir. Kişinin işinin gereği olarak iş arkadaşlarıyla veya halkla yakın temasta bulunması halinde de aynı sonuca varılmalıdır. Bunun sonucunda, çalışanlar sağlık yardımlarından ve iş göremezliklerine bağlı olarak ilgili yardımlardan yararlandırılmalıdırlar. ${ }^{40}$

İşçi Sağlığı ve İş Güvenliği Meclisi’nin sendikaların ve odaların rapor ve tespitleri ile basına yansıyan ve işyerlerinden ulaşan bilgilere göre yayımladığı raporda 2020 yılında, en az Covid-19 nedeniyle 741 çalışan (iş̧̧i, memur, bağımsız çalışan dahil) Covid-19 sebebiyle hayatını kaybettiği belirtilmektedir. ${ }^{41}$ Türk Tabipler Birliği’ne göre 2020 yılında Covid-19 sebebiyle 320 sağlık çalışanı

\footnotetext{
${ }^{38}$ SGK Başkanlığı Emeklilik Hizmetleri Genel Müdürlüğünün 2020/12 No’lu Genelgesi. Danıştay 10. Dairesi, 29.9.2020 tarihli kararıyla genelgeye karşı açılan davada yürütmenin durdurulması istemini reddetmiştir (Esas No. 2020/3420).

${ }^{39}$ ŞAHIN EMİ, s.586; YÜREKLİ, Sabahattin: "Çalışma Hayatında Koronavirüs (Covid-19) Salgınının Etkileri, İstanbul Ticaret Üniversitesi Sosyal Bilimler Dergisi Covid-19 Hukuk Özel Sayısı”, 19(38), s.47

${ }^{40}$ ILO CEACR: "Report of the Committee of Experts on the Application of Conventions and Recommendations of the International Labour Organization concerning social security measures taken at national level in response to the COVID19 pandemic", 91st Session Geneva 25 November-12 December 2020, s.10. https://rm.coe.int/ceacr-2020-reportcovid-19-eng/1680a19042. Erişim Tarihi: 14.5.2021.

41 İşçi Sağlığı ve İş̧ Güvenliği Meclisi: “2020 İş $\quad$ Cinayetleri Raporu”,
} http://www.isigmeclisi.org/site_icerik/2021/1ocak/1rapor.pdf, Erişim Tarihi: 15.1.2021. 
yaşamını yitirmiştir. ${ }^{42}$ Kanımızca, salgın sürecinde aktif olarak (evde çalışma, ücretli veya ücretsiz izin gibi uygulamalara gidilmeksizin) işyerlerinde çalışmaya devam eden sigortalıların sigortalının hastalığı işyerinde veya işle ilgili süreçlerde kaptığına dair bir kanaatin oluştuğu hallerde bunun kesin ispatı aranmaksızın, SSGSSK'nin 13. maddesinin sosyal güvenlik korumasını genişletmeyi amaçlayan düzenlemesine uygun olarak sigortalı, iş kazası ve meslek hastalığı sigortasından sağlanan edimlerden yararlandırılmalıdır. Örneğin, aşağıda ayrıntılı olarak açıklanacağı üzere, market kasiyerleri, kargo çalışanları gibi kişiler çok sayıda üçüncü kişiyle temas halindedir. Bu kişilerin filyasyon raporlarında kendi sosyal çevrelerinden kimse yoksa, hastalığa işleriyle bağlantılı olarak yakalanmaları yüksek bir olasılıktır. Bu tür bir yorum ILO Uzmanlar Komitesi'nin yukarıda anılan görüşüyle de uyumludur. Sigortalının işyerinde intiharının veya üçüncü kişi tarafından kasten öldürülmesinin dahi iş kazası olarak nitelendirildiği bu sistemde ${ }^{43}$, salgın süresince çalışmaya devam eden sigortalıların iş kazası ve meslek hastalığ sigortasından yararlanmasına yönelik bir yoruma gitmek kanunun amacına ve ruhuna uygun olacaktır. Sağlık çalışanları bakımındansa, yukarıda da ifade edildiği üzere hastalığın meslek hastalıkları listesine alınması makul bir çözüm sunabilecektir.

\section{ISŞÇILERIN TAZMINAT TALEP HAKLARI: ISSVERENIN KUSURUNUN BELIIRLENMESİ VE UYGUN İLLIYYT BAĞININ KURULMASI}

İşverenin işçiyi gözetme borcuna aykırı davranışı sonucunda işçinin hastalık veya kazaya uğraması ya da ölümü halinde maddi zararın SGK tarafından karşılanmayan kısmı ve manevi zararın tazmini için işverene başvurulması gerekir ${ }^{44}$. Kaza veya hastalığa uğrayan işçi hayattaysa, maddi ve manevi tazminat hakk1 kendisine aittir. Maddi zarar olarak tazmin edilecek unsurlar TBK m.54 uyarınca tedavi giderleri, kazanç kaybı, çalışma gücünün azalmasından ya da yitirilmesinden doğan kayıplar ve ekonomik geleceğin sarsılmasından doğan kayıplardır. İşçinin ağır bedensel zarara uğraması halinde TBK m.56/2 uyarınca işçinin yakınları da manevi tazminat talebinde bulunabilir ${ }^{45}$. İşçinin ölümü halinde işverenin, TBK m.53 uyarınca cenaze giderleri, ölüm hemen gerçekleşmemişse tedavi giderleri ile çalışma gücünün azalmasından ya da yitirilmesinden doğan kayıplar, ölenin desteğinden yoksun kalan kişilerin bu sebeple uğradıkları kayıpları karşılaması gerekir. TBK m.56/2 uyarınca ölen işçinin yakınları işverenden manevi tazminat talep edebilir ${ }^{46}$. Covid-19 salgını bakımından da işçinin işverenin gerekli iş sağlığı ve önlemlerini almaması şeklinde ortaya çıkan kusurlu davranış sonucunda, yaptığı işle illiyet bağ 1 içerisinde hastalanması halinde işverenin belirtilen çerçevede tazminat sorumluluğu gündeme gelecektir. Bu kısımda söz konusu tazminatların hesap yöntemlerine yer verilmeyecek, işverenin tazminat sorumluluğunun ortaya çıkması için gerekli unsurlardan işverenin işçiyi gözetme borcundaki kusuru ile uygun illiyet bağ 1 ve kesilmesi incelenecektir.

\section{A. İşverenin İşçiyi Gözetme Borcunu Yerine Getirmekteki Kusuru}

İşverenin iş kazası ve meslek hastalığından kaynaklanan tazminat sorumluluğunun esasının kusur sorumluluğu mu yoksa kusursuz sorumluluk mu olduğu öğretide uzun süre tartış1lmıştır. Yargitay, daha eski kararlarında kusursuz sorumluluk esasını benimserken, 2006 yılı ve sonrasında verdiği kararlarda, işverenin tazminat sorumluluğunu kusur esasına dayandırmıştır ${ }^{47}$. İşverenin işçiyi gözetme borcundaki kusuru, alınması gereken sağlık ve güvenlik önlemlerini almayarak işçinin hastalanmasına veya kazaya uğramasına sebep olmak şeklinde ortaya çıkar. İşverenin kusurlu olup olmadığının belirlenmesi, gözetme borcu kapsamında alınması gereken sağlık ve güvenlik önlemlerinin kapsamının belirlenmesi ile mümkün olur.

\footnotetext{
${ }^{42}$ Türk Tabipleri Birliği: https://siyahkurdele.com, Erişim Tarihi: 15.1.2021.

${ }^{43}$ İşyerinde intiharın iş kazası sayıldığı yönünde, Yarg. 10. HD 29.3.1979 8413/2759, YKD, Ağustos 1979, s.1167-1169. Sigortalının işyerinde öldürülmesinin iş kazası sayıldığı yönünde, Yarg. 10. HD. 4.2.1980, 1979/6497, 1980/624, www.kazanci.com.tr, Erișim Tarihi: 15.7.2020.

${ }^{44}$ AKIN, Covid-19, s.26.

45818 sayılı Borçlar Kanunu zarar görenin hayatta bulunması durumunda yakınlarına manevi tazminat hakkı tanımamakla beraber, Yargıtay 21. Hukuk Dairesi, bazı kararlarında işçinin bedensel zararı ağır olmasa dahi Yakınlarının çektiği üzüntüyü dikkate alarak işçinin yakınları için manevi tazminat takdir etmekteydi. Örneğin, 21. Hukuk Dairesi'nin 15.1.2002 tarih ve 9272/371 sayılı kararda, işgöremezlik oranı \%13 olan bir işçinin yakınlarına, işçinin hayati tehlike geçirmiş olması dikkate alınarak manevi tazminat ödenmesine karar verilmiştir. 6098 sayılı TBK'nın yürürlüğe girmesiyle içtihattaki bu gelişme de son bulmuştur. Yargıtay'ın eğilimi ve yakınların manevi tazminat talebinde ağır bedensel zarar şartının kaldırılması gerektiği yönündeki görüş bkz. BAYCIK, Gaye: "Çalışanların İş Sağlığı ve Güvenliğine İlişkin Haklarında Yeni İş Kazası ve Meslek Hastalığı Nedeniyle İşverenin Sorumluluğu Düzenlemeler”, Ankara Barosu Dergisi, 2013/3, s.152-154; Covid-19 salgını bakımından, işçi hastalık sebebiyle ağır bedensel zarara uğramasa dahi, hayati tehlike atlatması halinde 6098 sayılı TBK' daki açık hüküm gereği yakınların manevi tazminat talep etmesi mümkün olmayacaktır. ${ }^{46}$ SÜZEK, s.437-444.

${ }^{47}$ SÜZEK, s.413-417; ÇELIK/CANIKLIOOĞLU/CANBOLAT, s.419-420; BAYCIK, s.131-132.
} 
İşverenin işçiyi gözetme borcu, işçinin işyerinde ve işle ilgili süreçlerde sağlık ve güvenliğini sağlanma yükümlülüğü getirir. Söz konusu borcun yasal dayanağı TBK m.417/2 ve İSGK m.4'te bulunabilir. TBK m.417/2'ye göre işveren, işyerinde iş sağlı̆̆ ve güvenliğinin sağlanması için gerekli her türlü önlemi almak, araç ve gereçleri noksansız bulundurmakla yükümlüdür. İSGK m.4/1 uyarınca "Işveren, çalışanların işle ilgili sağllk ve güvenliğini sağlamakla yükümlü olup bu çerçevede; a) Mesleki risklerin önlenmesi, eğitim ve bilgi verilmesi dâhil her türlü tedbirin alınması, organizasyonun yapılması, gerekli araç ve gereçlerin sağlanması, sağlık ve güvenlik tedbirlerinin değişen şartlara uygun hale getirilmesi ve mevcut durumun iyileştirilmesi için çallşmalar yapar. b) Issyerinde alınan iş sağlığı ve güvenliği tedbirlerine uyulup uyulmadığın izler, denetler ve uygunsuzlukların giderilmesini sağlar. c) Risk değerlendirmesi yapar veya yaptırır. ç) Çalışana görev verirken, çalışanın sağlık ve güvenlik yönünden işe uygunluğunu göz önüne alır. d) Yeterli bilgi ve talimat verilenler dişındaki çalışanların hayati ve özel tehlike bulunan yerlere girmemesi için gerekli tedbirleri alır." İşverenin iş sağlığı ve güvenliğini sağlama yönündeki yükümlülüğü işçileri işyerinde ve işyeri dışında Covid-19'a karşı korumak üzere alınabilecek önlemlerin alınmasını zorunlu kılar. Covid-19'un daha önce bilinmeyen ve yeni ortaya çıkmış olan bir hastalık olması işverenin önlem alma yükümlülüğünü değiştirmez, zira İSGK m.4/1-a'da işverenin sağlık ve güvenlik tedbirlerini değişen şartlara uygun hale getirme yükümlülüğü açıkça düzenlenmiştir. İşveren, Covid-19 salgını döneminde mal ve hizmet üretimine devam edecekse, İSGK m.4 uyarınca alınabilecek her türlü önlemi almak zorundadır. İşveren işçilerin Covid-19 hastalığına yakalanma riskini işyeri düzeyinde bilimsel gelişmeler çerçevesinde alınması gereken önlemleri alarak bertaraf etmek durumundadır ${ }^{48}$.

İşverenin, işyerinde Covid-19'a karşı bilimsel ve tıbbi gelişmelerin gerektirdiği en güncel önlemleri almanın yanında, İSGK'da yer alan diğer yükümlülüklerini yerine getirirken de salgını dikkate alması gerekmektedir. $\mathrm{Bu}$ bağlamda, öncelikle risk değerlendirmesinin yenilenmesi gerekmektedir. Zira, Risk Değerlendirmesi Yönetmeliği m.12/2-f uyarınca işyeri dışından kaynaklanan ve işyerini etkileyebilecek yeni bir tehlikenin ortaya çıkması halinde risk değerlendirmesinin yenilenmesi zorunludur ${ }^{49}$. İSGK m.17/1 uyarınca, işverenin değişen risklere göre iş sağlığı ve güvenliği eğitimlerini yenileme yükümlülüğü vardır; işverenin Covid-19 salgınının ortaya çıkmasıyla beraber oluşan yeni risk üzerine eğitimleri yenilemesi gerekir. Ayrıca, İSGK m.15 uyarınca yerine getirilen sağlık gözetimleri de salgın koşullarına uyarlanmalıdır ${ }^{50}$.

İşverenin işçiyi gözetme borcunun kapsamında alması gereken önlemlerin düzeyi ve neler olduğu, teknolojideki ve bilimdeki en son gelişmelere göre belirlenir. Dolayısıyla işverenin mevzuatta yer almasa dahi gelişen bilim ve teknolojinin getirdiği önlemleri alma yükümlülüğü vardır ${ }^{51}$. İşverenin sadece mevzuatta yer alan önlemleri almasının gözetme borcunu tam olarak yerine getirdiği anlamına gelmeyeceği, yeni gelişmelerle ortaya çıkan önlemlerin alınmamasının gözetme borcu ihlali sonucu doğurabileceği Yargıtay tarafından kabul edilmektedir ${ }^{52}$. Covid-19'a ilişkin bilimsel araştırmaların hızla ilerlemesi karşısında işverenin söz konusu gelişmeleri takip etmesi, işçiyi gözetme borcunun tam olarak yerine getirmesi için büyük önem taşımaktadır. Bu dönemde, başta Sağlık Bakanlığı ve Aile, Çalışma ve Sosyal Hizmetler Bakanlığı olmak üzere ilgili kamu kurum ve kuruluşlarının hazırladığı rehberlerin güncel olarak titizlikle takip edilmesi gerekir. Örneğin, Aile, Çalışma ve Sosyal Hizmetler Bakanlığı, "İ̧̧yerinde Yeni Tip Koronavirüse Karşı Alınması Gereken Önlemler” başlıklı bir belge yayımlamış ve çeşitli işyerleri için alınması gereken önlemlere dair kontrol listeleri oluşturmuştur ${ }^{53}$. Sağlık Bakanlığı da sektörlere göre hem işçileri hem de müşterileri korumaya yönelik rehberler yayımlamışıır ${ }^{54}$. Bu rehberlerde yer alan önlemlere uyulmaması, işçilerin Covid-19'a yakalanmaları

\footnotetext{
${ }^{48}$ AKIN, Covid-19, s.18.

49 ARSLAN DURMUŞ, s.375.

${ }^{50}$ Sağlı gözetimi ve işyeri hekimlerinin rolüyle ilgili ayrıntılı bilgi için bkz. İZMIRLİOĞLU, Ayça: "İşverenin Sağlık Gözetimi Sağlama Yükümlülüğüne COVID-19 Salgını Bağlamında Genel Bir Bakıș”, İstanbul Hukuk Mecmuası, 78(2), 2020, s.455-483.

51 EREN, Fikret: Borçlar Hukuku ve İş Hukuku Açısından İşverenin İş Kazası ve Meslek Hastalığından Doğan Sorumluluğu, (İş Kazası) AÜHF Yayınları, Ankara 1974, s.41; SÜMER, Haluk Hadi: İş Sağlığı ve Güvenliği Hukuku, 3. Bas1, Seçkin Yayınları, Ankara 2019, s.106; SÜZEK, s.410-411; ÇELIK/CANIKLİOĞLU/CANBOLAT, s.418; AKIN, s.44; SERATLI, s.24.

52 Yarg. HGK. 16.6.2004, 21-365/369; Yarg. HGK. 16.10.1985, 10-197/82; Yarg. 10. HD. 9.11.1998 7518/7851 www.kazanci.com, Erişim Tarihi: 4.7.2020.

53 T.C. AÇSHB İSGÜM: "İşyerinde Yeni Tip Koronavirüse Karşı Alınması Gereken Önlemler", https://ailevecalisma.gov.tr/media/43190/covid-19_isyerinde_alinmasi_gereken_onlemler_2_19042020_2337.pdf.,

Erişim Tarihi: 4.7.2020; Ayrıca işyerlerine göre oluşturulmuş kontrol listelerine https://ailevecalisma.gov.tr/covid19 adresinden ulaşılabilir.

${ }^{54}$ T.C. Sağlık Bakanlığı: "Covid-19 Salgın Yönetimi ve Çalışma Rehberi Bilimsel Danışma Kurulu Çalışması (25.6.2020)",https://covid19bilgi.saglik.gov.tr/depo/toplumda-salgin-yonetimi/salgin-yonetimi-ve-calisma-
} 
halinde işverene kusur olarak atfedilebilir. İşveren kamu kurum ve kuruluşlarının uyarı ve tavsiyelerinin yanında, Covid-19 hastalı̆̆ıyla mücadeledeki bilimsel ve teknolojik gelişmeleri takip etmek zorundadır. İşveren, somut olarak tıp ve mühendislik alanlarındaki meslek örgütlerinin uyarılarını, Dünya Sağlık Örgütü’nün ve Uluslararası Çalışma Örgütü’nün (ILO) tavsiyelerini takip etmelidir. Somut bir örnekle açıklamak gerekirse, Çin'de Covid-19 hastalı̆̆ının havada, havalandırma ve klimalar aracılığıyla daha uzağa yayılabildiği tespit edilmiştir ${ }^{55}$. TMMOB Makine Mühendisleri Odası, havalandırma ve klima sistemlerinin virüsün yayılmasındaki etkileri ve bunun için alınabilecek önlemleri içeren açıklamalar yapmıştır ${ }^{56}$. Yapılan öneriler arasında, işyerlerinde iç mekan havası veya karışım havayla çalışan klima ve havalandırma cihazlarının çalıştırılmaması, bu cihazlara takılması gereken filtre türlerinin neler olduğu bulunmaktadır. Bu tür uyarıların varlığına ve kolayca erişilebilir olmasına rağmen, işverenin risk faktörü olan mevcut havalandırma sistemini değişiklik yapmaksızın kullanması sebebiyle işçilerin hastalanmaları durumunda işveren kusurlu olacaktır.

İşverenin işçiyi gözetme borcu bağlamındaki kusuru, objektif bir ölçüte göre belirlenecektir. Buna göre işverenden gözetme borcunu yerine getirirken, dürüst, makul, dikkatli ve sorumluluk duygusu taşıyan bir işverenin göstereceği özeni göstermesi beklenir. Dolayısıyla işverenin kişisel bilgi, tecrübe, mali durumu gibi nitelikleri göz önünde bulundurulmaz. İşveren, özellikle bu yeni gelişen önlemleri takip etmenin özel bir bilimsel ve teknik bir bilgiyi gerektirdiğini veya benzer işyerlerinde de önlemlerin alınmadığını ileri sürerek sorumluluktan kurtulamaz ${ }^{57}$. Covid-19 bakımından alınması gereken önlemler bağlamında, yukarıdaki havalandırma örneğinden devam edilecek olursa, işveren havalandırmanın yarattığı riskleri bilmediğini, bu risklere karşı alınması gereken önlemlerle ilgili bilgilerin kendi anlamayacağı teknik bilgiler olduğunu, alınması gereken önlemler arasında önerilen HEPA filtreli havalandırma cihazlarını satın almaya ekonomik gücünün yetmediğini veya diğer işyerlerinde de mevcut havalandırma cihazlarının kullanılmaya devam edildiğini ileri süremeyecektir.

Sonuç olarak, işverenin mevzuatta yer alan veya mevzuatta yer almamakla beraber bilimsel ve teknolojik gelişmeler sayesinde ortaya çıkan önlemleri almaması işverenin işçiyi gözetme borcunu yerine getirirken kusurlu davrandığı anlamına gelecektir. Covid-19 bakımından işverenin kusurlu davranışları, hastalık riskini azaltmaya uygun maske, siperlik, önlük gibi kişisel koruyucu donanımın işçilere sağlanmaması, kişisel koruyucu donanımın gerekli kalitede olmaması veya yeterli sayıda verilmemesi, işyerinde sosyal mesafe kurallarına uygun bir ortamın sağlanmaması, işyerinde hijyen kurallarına uygun bir ortamın olmaması, havalandırmanın sağlanmaması, Covid-19 önlemleriyle ilgili gerekli bilgilendirme ve eğitimin yapılmaması, işçilerin önlemlere uyup uymadığının denetlenmemesi gibi çok çeşitli şekillerde ortaya çıkabilir. Covid-19'a karşı alınacak önlemlerin türlerinin ve düzeyinin belirlenmesinde, hastalığın önlenmesine yönelik bilimsel gelişmelerin ve önerilerin takip edilmesi özel önem arz eder ve bunun yapılmaması işverene kusur olarak atfedilebilir.

\section{B. İşverenin Kusurlu Davranış İle İşçinin Covid-19 Hastalığına Yakalanması Arasında Uygun İlliyet Bağının Varlığı}

1. Uygun İlliyet Bağının Kurulması ve Filyasyonun Etkisi

İşverenin iş kazası bakımından tazminat sorumluluğunun bulunması için iki türlü illiyet bağı aranır. Öncelikle, kaza veya meslek hastalığ ile zarar arasında uygun illiyet bağının bulunması gerekir. Örneğin, iş̧̧inin iş kazası sebebiyle hastanede tedavi görmekteyken çıan bir yangın sebebiyle hayatını kaybetmesi durumunda artık ölüm olayı ile iş kazası arasında uygun illiyet bağı kopmuştur. Aynı şekilde hastanede Covid-19 tedavisi gören işçinin, hayatını bir yangın veya depremde kaybetmesi durumunda Covid-19 hastalı̆̆ı ile ölüm olayı arasında uygun illiyet bağı yoktur. Kaza ve zarar arasında aranan bu ilk illiyet bağı, kazanın sosyal güvenlik hukuku anlamında iş kazası sayılması ve işçiye veya

\footnotetext{
rehberi/COVID-19_SALGIN_YONETIMI_VE_CALISMA_REHBERI.pdf, Erişim Tarihi: 4.7.2020. Alınabilecek önlemlerle ilgili somut örnekler için ayrıca bkz. ATEŞ, Zehra Gizem: “Covid-19'un İşverenin İş Sağlığı ve Güvenliği Konusunda Alması Gereken Önlemlere Etkisi”, İstanbul Ticaret Üniversitesi Sosyal Bilimler Dergisi Covid-19 Hukuk Özel Sayıs1, 19(38), s.161-179.

${ }^{55} \mathrm{LU}$, J./GU, J./LI K. ve diğerleri: COVID-19 Outbreak Associated with Air Conditioning in Restaurant, Guangzhou, China, 2020, Emerging Infectious Diseases, 2020, 26(7), s.1639.

56 Makina Mühendisleri Odası: "Coronavirüs ve Salgın Hastalıkların Hvac Sistemleriyle İlişkisi”" : https://www.mmo.org.tr/merkez/duyuru/coronavirus-ve-salgin-hastaliklarin-hvac-sistemleriyle-iliskisi. Erişim Tarihi: 4.7.2020; Makina Mühendisleri Odası, "AVM'ler, İşyerleri ve Toplu Bulunulan Mekânların Tesisatlarında Mutlaka Alınması Gereken Corona Virüs Önlemleri” https://www.mmo.org.tr/merkez/basin-aciklamasi/avmler-isyerleri-ve-toplubulunulan-mekanlarin-tesisatlarinda-mutlaka, Erişim Tarihi: 4.7.2020.

${ }^{57}$ SÜZEK, Sarper: İş Güvenliği Hukuku, Savai Kitabevi, Ankara 1985. s.244; SÜZEK, s.417-418; EREN, İş Kazas1, s.92; SÜMER, s.214; ÖZDEMIR, s.68; SERATLI, s.60.
} 
ölmüşse yakınlarının SSGSSK uyarınca yapılacak ödemelere hak kazanması için de gereklidir ${ }^{58}$.

İşverenin iş kazasından sorumlu tutulabilmesi için aranacak ikinci tür illiyet bağı, kazanın işverenin yürüttüğü iş ile uygun illiyet bağı içinde bulunmasıdır ${ }^{59}$. Bu illiyet bağı, işverenin sorumlu tutulduğu bireysel iş hukuku anlamındaki iş kazasını, sosyal güvenlik hukuku anlamındaki iş kazasından ayıran unsuru oluşturur; zira yukarıda ele alındığı üzere SSGSSK m.13'te sayılan yer ve zamanlarda gerçekleşen iş kazasının yürütülen işle ilgili olması gerekmez ${ }^{60}$. Dolayısıyla işçinin Covid19 hastalı̆̆ına yakalanmasının bireysel iş hukuku anlamında iş kazası sayılması ve işverenin tazminat sorumluluğunun doğması için, işçinin hastalığ iş̧ten kaynaklanan sebeplerle kapmış olması gerekir ${ }^{61}$. İşverenin iş kazasından sorumlu tutulabilmesi için olayın işyerinde meydana gelmesi yeterli olmayıp yapılan işle bağlantılı olarak ortaya çıkmış olması gerekir; dolayısıyla işyerinde gerçekleşen her kaza işverenin tazminat sorumluluğunu doğurmaz. Buna karşılık kazanın işyeri dışında gerçekleşmesi de işverenin sorumlu olmadığı anlamına gelmez; işyeri dışında ancak işin görülmesiyle bağlantılı olarak gerçekleşen iş kazasında işverenin tazminat sorumluluğu doğar ${ }^{62}$. Covid-19 bağlamında örneğin, işyerine ara dinlenmesinde dışarıdan gelen bir ziyaretçisiyle kurallara uymaksızın sarılıp öpüştüğü için hastalanan işçi bakımından işverenin tazminat sorumluluğu bulunmayacaktır. Öte yandan, bir kargo işçisinin işyeri dışında teslimat yaparken görüştüğü bir müşteriyle teması sebebiyle hastalanması halinde, işverenin maske sağlamamak veya eğitim vermemek gibi bir kusuru varsa tazminat sorumluluğu ortaya çıkabilecektir.

İşverenin Covid-19'a yakalanan işçilere karşı tazminat sorumluluğu teorik olarak yukarıdaki çerçevede özetlenebilecekse de hastalığın solunum yoluyla ve temasla kolay bulaşabilmesi, işçinin hastalığı işle bağlantılı olarak mı yoksa iş dışında $\mathrm{m} ı$ kaptığının belirlenmesini pratikte son derece güçleştirmektedir. $\mathrm{Bu}$ bağlamda filyasyon raporları uygun nedensellik bağının kurulmasında önemli bir dayanak noktası oluşturacaktır ${ }^{63}$. Sağlık Bakanlı̆̆ı'nın Bulaşıcı Hastalıklarla Mücadele Rehberi’nde yer alan tanıma göre filyasyon veya saha incelemesi hastalık kaynağın ve etkenin belirlenmesine yönelik çalışma yapılması ve/veya temaslılar dahil koruma ve kontrol önlemlerinin alınmasıdır ${ }^{64}$. Filyasyonda amaç etkenin ve kaynağın erken dönemde saptanarak hastalığın yayılmasının önlenmesidir. Hastanın son iki günlük detaylı hikayesi alınır, hastanın bu süre içinde kimlerle ne kadar süre ve nerede görüştüğü sorgulanır. Aile bireyleri, yakınları, iş arkadaşları, komşuları, seyahat ettiği araçlarda ve sosyal hayatta temas kurduğu bireylerin bilgileri alınır. Filyasyon ekipleri bu kişileri ziyaret ederek hikayelerini alır ve gerektiğinde test uygular ve bunun sonucuna göre izlenecek tedavi veya izolasyon gibi uygulamalar belirlenir ${ }^{65}$. Filyasyon raporlarının iş kazasında uygun illiyet bağına etkisi bakımından dikkate alınması gereken bir husus, hastalığın kuluçka süresi 2-14 gün arasında değişebilmekte olduğudur ${ }^{66}$. Buna karşılık, filyasyon uygulamasında hastanın son iki gündür temaslı olduğu kişilere dair bir araştırma yapılmaktadır; dolayısıyla uygun illiyet bağına ilişkin değerlendirmelerde kanımızca filyasyon raporlarına mutlak bir etki tanımamak gerekir.

Covid-19 tanısı alan bir işçinin filyasyon raporunda çalışma arkadaşlarının bulunması durumunda hem söz konusu işçi hem de işyerinde çalışan diğer işçiler bakımından hastalık ve iş arasında uygun nedensellik bağının kurulduğu sonucuna varılabilecektir ${ }^{67}$. Aynı işyerinde çalışan birden fazla işçinin hastalandığı durumda, işverenin işyerinde aldığı önlemlerin hastalığın iş̧̧iler arasında bulaşmasını engellemek için yetersiz olduğu açıktır. Bu halde hastalık ve iş arasında uygun illiyet bağı kurulabildiği ve işverenin de işçiyi gözetme borcunda kusurlu davranışları bulunduğu için işverenin işçilere karşı maddi ve manevi tazminat sorumluluğu söz konusu olacaktır.

İşçinin filyasyon raporunda temaslı bulunduğu kişiler arasında çalışma arkadaşlarının bulunmaması halinde zarar ile iş arasındaki uygun nedensellik bağının kurulmasının büyük ölçüde

\footnotetext{
${ }^{58}$ ULUSAN, İlhan: İşverenin İşçiyi Gözetme Borcu ve Bundan Doğan Sorumluluğu, Kazancı Hukuk Yayınları, İstanbul 1990, s.78-79; AKIN, s.46-47; SERATLI, s.35.

${ }^{59}$ SÜZEK, s.423; EREN, İş Kazası, s.11; ÇELIK/CANIKLİOĞLU/CANBOLAT, s.415-416; AKIN, s.47; ULUSAN, s.73.

${ }^{60}$ AKIN, Covid-19, s.27; ULUSAN, s.75; SERATLI, s.31.

${ }^{61}$ AKIN, Covid-19, s.27; ARSLAN DURMUŞ, s.379.

62 SÜZEK, s.424; AKIN, s.47-48.
}

${ }^{63}$ AKIN, Covid-19, s.29.

64 T.C. Sağlık Bakanlı̆̆ı: "Bulaşıcı Hastalıklar ile Mücadele Rehberi”" https://dosyamerkez.saglik.gov.tr/Eklenti/27034,bulasici-hastaliklarek39189df2-1e9b-4866-8c87919b02695fd5pdf.pdf?0 Erişim Tarihi: 30.6.2020.

65 T.C. Sağlı Bakanlı̆̆ı: Filyasyon Nedir? Bilgilendirme Videosu

https://www.youtube.com/watch?v=zPw4ut5xT6g\&feature=youtu.be, Erişim Tarihi: 30.6.2020.

${ }^{66} \mathrm{https}: / /$ covid19bilgi.saglik.gov.tr/tr/sss/halka-yonelik.html

${ }^{67}$ AKIN, Covid-19, s.29; Arslan Durmuş, s.382. 
engellendiği ifade edilmektedir ${ }^{68}$. Bu ihtimalde kanımızca uygun nedensellik bağının kesildiği sonucuna varılabilmesi, işçinin yaptığı işin ne olduğu ile yakından ilgilidir. Örneğin, işçilerin farklı odalarda çalıştığı bir büro işyerinde sadece tek bir kişinin testinin pozitif çıkması halinde işle hastalık arasında uygun illiyet bağı kurulması güçtür. Aynı sonuca çok sayıda işçinin çalıştığı işyerlerinde izole tek bir hastalık vakasının bulunması halinde de varılabilir. Öte yandan, hastalanan işçinin çalışma arkadaşları haricinde çok sayıda üçüncü kişiyle görüşmek durumunda kaldığı işlerde filyasyon raporunun etkisi bakımından daha farklı bir değerlendirmeye gitmek gerekmektedir. Kasiyer, teknik servis işçisi veya kargo dağıtım işçisi gibi çok sayıda müşteriyle temas halinde olan işçiler bakımından, filyasyon raporunda çalışma arkadaşlarıyla temasın bulunmadığının görülmesi, yapılan iş ile hastalık arasında illiyet bağının kurulamayacağı sonucuna varılması için yeterli olmamalıdır. Örneğin, bir markette kasiyer olarak çalışan işçi çok sayıda müşteri ile temas halindedir. Böyle bir durumda eğer işçi, hastalanan bir müşterinin filyasyon raporundaki temaslı kişiler arasındaysa, işçi bakımından iş ve hastalık arasında uygun illiyet bağ 1 kurulacaktır. Benzer bir sonuca kargo çalışanları için de varılabilir; bu işlerde çalışan işçilerin temaslı olduğu müşterilerin adres ve kimlik bilgileri bilinebildiğinden hasta olan bir müşteriyle temasın tespiti sağlandıysa çalışma arkadaşlarından kimse hasta olmasa bile iş ve hastalık arasında uygun illiyet bağı vardır. Öte yandan özellikle kasiyer işçi örneğinde, işçinin temaslı olduğu tüm müşsterilerin tespiti mümkün olmayabilir. Bu durumda, iş̧̧inin sosyal çevresinde başka hastalanan kimse yoksa veya işçinin yakınları hastalansa bile bu kişilerin işçiden başka sosyal teması yoksa (iş̧̧inin 65 yaş üstü ebeveynleri, işçinin uzun süredir evden çıkmamış olan eşi gibi) işçinin hastalığı kendi sosyal yaşamında kapmadığı sonucuna varılacaktır. Buna karşılık, işçi iş hayatında çok sayıda müşteri ile temastadır; bu durumda özellikle işyerinde alınan önlemlerde eksiklikler varsa işçinin işi ve hastalık arasında uygun nedensellik bağının kurulduğu sonucuna varılmalıdır.

Covid-19 ve yapılan iş arasındaki uygun nedensellik bağının sağlık çalışanları bakımından özel olarak incelenmesi gerekir. Sağlık çalışanları işyerinde Covid-19 virüsünü alarak hastalandıklarında, hastalığın görülen iş veya işverenin iş sağlığı ve güvenliği önlemlerini alma borcuna aykırı davranışıyla uygun illiyet bağ 1 içerisinde olduğu sonucuna varılabilir ${ }^{69}$. Bu kişilerin işyerinde hastalığa maruz kalma riskinin büyüklüğü uygun illiyet bağının kurulmasını kolaylaştırmaktadır. Uygun nedensellik bağının tespiti bağlamında, sağlık çalışanı kavramı; hekim, hemşire, hasta bakıcı, acil tıp teknisyeni, radyoloji teknisyeni, eczacı gibi kişilerin yanında temizlik iş̧̧isi, ambülans şoförü, hastanedeki danışma personeli gibi hastalık tanı ve tedavisinde doğrudan rol almamakla beraber işi gereği hastalarla temas eden tüm çalışanları kapsayacak şekilde anlaşılmalıdır. Zira tüm bu çalışanlar, yaptıkları işin niteliği farklı da olsa, işleri gereği Covid-19 riskine maruz kalmaktadırlar ve hastalığın işleriyle olan illiyet bağı benzer şekilde ortaya çıkmaktadır. Sağlık çalışanları işverenin kusurlu davranışı sonucunda hastalandıklarında işverenin maddi ve manevi tazminat sorumluluğu ortaya çıkacaktır.

2. Uygun İlliyet Bağının Kesilmesi

İş kazası ve işverenin yürüttüğü iş arasındaki uygun illiyet bağı kesildiği takdirde işverenin tazminat sorumluluğu söz konusu olmaz. İlliyet bağını kesen sebepler, zarar görenin ağır kusuru, üçüncü kişinin ağır kusuru ve mücbir sebeptir ${ }^{70}$. Söz konusu sebeplerin Covid-19 salgını bakımından mevcut olup olmadığının değerlendirilmesi gerekmektedir.

İşçinin ağır kusurunun uygun illiyet bağını keserek işverenin tazminat sorumluluğunu ortadan kaldırması için, işverenin kusurlu davranışının kazanın temel sebebi olması ve yapılan iş ve kaza arasındaki bağlantıyı geri plana atmış olması gerekir. İşçinin ağır kusuru davranışı kasten gerçekleştirmesi zorunlu olmadığı gibi, bu davranışın \%100 kusur düzeyinde olması da gerekmez ${ }^{71}$. Covid-19 hastalı̆̆ına yakalanmak bakımından işçinin ağır kusuru işveren gerekli önlemleri aldığı, uyarılarda bulunduğu ve denetim yaptığı halde işçinin alınan önlemlere uymayarak hastalık kapması şeklinde ortaya çıkabilir. Örneğin, işçinin işini işyeri dışında gördüğü teknik servis, dağıtım gibi işlerde; işveren gerekli eğitimi vermiş, maske, eldiven, dezenfektan gibi malzeme ve kişisel koruyucu donanımı gerekli kalitede ve yeterli sayıda sağlamış, bunların kullanımının gerekliliği konusunda uyarılarda bulunmuş, hatta söz konusu malzemenin kullanılıp kullanılmadığını işyerine dönüşte işçinin elinde kalan malzeme sayısı ve miktarı üzerinden kontrol etmiş olabilir. Tüm bu önlemlere rağmen, çalışma sırasında maske ve eldiven kullanmayan ve denetimlerde işvereni yanıltmak için elindeki malzemeyi atarak yok eden işçi hastalanırsa bu hastalığı kapmakta ağır kusurlu olacaktır ve işverenin

\footnotetext{
${ }^{68}$ AKIN, Covid-19, s.29.

${ }^{69}$ AKIN, Covid-19, s.29.

${ }^{70}$ SÜZEK, s.425.

${ }^{71}$ SÜZEK, s.426; EREN, Fikret: Sorumluluk Hukuku Açısından Uygun İlliyet Bağı Teorisi, (İlliyet Bağı) AÜHF Yayınları, Ankara 1975, s.187.
} 
tazminat sorumluluğu ortadan kalkacaktır.

İşçinin olayda illiyet bağını kesecek düzeyde kusurunun bulunmaması halinde, işverenin tazminat sorumluluğu ortadan kalkmaz ancak tazminattan işçinin ortak kusuru oranında indirim yapı1ır ${ }^{72}$. İşçinin Covid-19'a yakalanması bakımından illiyet bağını kesecek düzeyde ağır kusurlu olmayıp ortak kusurlu olduğu hallerle daha sık karşılaşılabilir. İşverenin işyerinde ve işle ilgili tüm sağlık ve güvenlik önlemlerini alması yeterli olmayıp aynı zamanda bunlara uyulup uyulmadığını denetleme yükümlülüğü vardır ${ }^{73}$. Yargıtay da işverenin sadece önlem almakla yetinemeyeceğini, bunlara uyulup uyulmadığını denetlemekle yükümlü olduğuna karar vermiştir ${ }^{74}$. İşveren söz konusu önlemlere uymayan işçilere disiplin yaptırımları uygulayabileceği gibi, İK m.25/II-1 gereği, haklı nedenle derhal fesih yetkisine dahi sahiptir. Dolayısıyla, Covid-19 bakımından da işveren sadece gerekli koruyucu malzemeyi sağlar ancak bunların kullanılıp kullanılmadığını denetlemezse veya işyerine sosyal mesafe konusunda posterler asıp sosyal mesafe kurallarına uyulmamasına göz yumarsa, söz konusu kurallara uymayan işçilerin hastalanmaları durumunda işçilerin ortak kusurlu davranışı illiyet bağını kesmez ve işverenin tazminat sorumluluğu söz konusu olur.

Üçüncü kişinin tam veya ağır kusuru da iş kazasında illiyet bağını kesebilir ${ }^{75}$. Bir iş̧̧inin Covid19'a yakalanması bakımından üçüncü kişinin ağır kusurunun illiyet bağını kesmesi mümkün olabilir. Örneğin, Covid-19 tanısı almış bir kişinin tedavi olmamak için hastaneden kaçmaya çalışması sırasında, hastanın kendisini zapt etmeye çalışan hastabakıcının siperlik ve maskesini çıkarması gibi bir durumda üçüncü kişinin kusuru illiyet bağını kesecek ağırlıktadır. Üçüncü kişinin kusuru illiyet bağını kesecek düzeyde değilse, birden çok kişi birlikte bir zarara sebebiyet verdikleri veya aynı zarardan çeşitli sebeplerden dolayı sorumlu oldukları takdirde, haklarında müteselsil sorumluluğa ilişkin hükümlerin uygulanacağını öngören TBK m.61 gereği, işveren ve üçüncü kişi tazminatlardan müteselsilen sorumlu olacaktır. Burada işverenin sorumluluğu iş sözleşmesindeki işçiyi gözetme borcunun ihlaline dayanırken, üçüncü kişinin sorumluluğu haksız fiiline dayanmaktadır. Hastaneden kaçmaya çalışan Covid-19 tanısı almış kişinin kendisine engel olmak isteyen hastabakıcıya hastalık bulaştırması örneğinde, işveren hastabakıcıya gerekli kişisel koruyucu donanımı sağlamamışsa bu durumda hastanın davranışı illiyet bağını kesmez. Hem hasta hem de işveren, hastabakıcıya karşı müteselsilen sorumlu olurlar.

İş kazasının mücbir sebep sonuncunda meydana gelmesi illiyet bağını keser ${ }^{76}$. Mücbir sebebin yasal bir tanımı olmamakla beraber öğretide "sorumlu veya borçlunun faaliyet ve işletmesi dışında meydana gelen, genel bir davranış normunun veya borcun ihlâline mutlak olarak kaçınılmaz bir şekilde yol açan, öngörülmesi ve karşı konulması mümkün olmayan olağanüstü bir olay" olarak tanımlanmaktadır ${ }^{77}$. Bu tanıma göre mücbir sebebin unsurları; bir olayın ortaya çıkması, olayın zarar verenin faaliyet ve işletmesi dışında meydana gelen harici bir olay olması, bir davranış normunun veya sözleşmeden doğan bir borcun ihlali, mücbir sebebin borca aykırılığın sebebini oluşturması, kaçınılmazlık ve doğurduğu sonuçların öngörülmez olmasıdır ${ }^{78}$. Kanımızca Covid-19 salgınının işverenin hukuki sorumluluğuna yol açan bir iş kazası olup olmadığının belirlenmesi bakımından üzerinde durulması gereken husus salgının kaçınılmazlık niteliği taşıyıp taşımadığıdır. Kaçınılmazlık, "teknik ve bilimin o andaki verilerine göre, mevcut her türlü tedbir alınsa, her türlü özen gösterilse bile, ihlâlin ve dolayısiyle zararlı sonucun hiç kimse tarafindan önlenmemesi"ni ifade eder. Burada kaçınılmazlık, mutlak ve objektif olarak değerlendirilir ve borçlunun durumu dikkate alınmaz; yani işverenin ve işletmesinin özellikleri bir durumun mücbir sayılmasını etkilemez ${ }^{79}$. Kaçınılmazlık unsurunun Covid-19 bakımından değerlendirilmesinde salgının seyri önem taşır. Covid-19 olarak adlandırılan yeni tip coronavirüs ilk olarak Çin'in Wuhan kentinde Aralık 2019'da görülmüş ve 31 Aralık 2019'da Çin tarafından Dünya Sağlık Örgütü'ne bildirilmiştir. Virüs 2020 yılının Ocak ayından itibaren dünyanın çeşitli ülkelerinde görülmeye başlanmış ve Türkiye'de ilk vaka 11 Mart 2020 günü tespit edilmiştir ${ }^{80}$. Hastalık ilk ortaya çıktığında karşı konulamaz ve önlenemez nitelik taşımaktaysa da, zaman içerisinde koşullar değişmiştir. Hastalığın tedavisi bulunamamış olsa da bulaşmasını

\footnotetext{
72 SÜZEK, s.426; EREN, İlliyet Bağı, s.187.

${ }^{73}$ SÜZEK, s.891-892.

${ }^{74}$ Yarg. 10. HD. 31.10.1978, 2077/7689, www.kazanci.com.tr, Erişim Tarihi: 7.7.2020.

${ }^{75}$ SÜZEK, s.426.

${ }^{76}$ SÜZEK, s.426.

${ }^{77}$ EREN, İlliyet Bağ 1 , s. 175 .

${ }^{78}$ EREN, İlliyet Bağ 1 , s.176-183.

${ }^{79}$ EREN, İlliyet Bağı, s.181-183.

${ }^{80}$ BAĞ, Mustafa/SADE, Gizem: “Dünyada Covid-19: İlk 4 ayında neler yaşandı? Salgının seyri ne durumda?” (4.5.2020) https://tr.euronews.com/2020/05/04/dunyada-covid-19-salg-n-n-ilk-100-gununde-yasananlar-ilk-nerede-ortaya-c-kt-nas1-yay-ld,, Erişim Tarihi: 7.7.2020.
} 
engellemeye yönelik çareler tespit edilmiş ve bu yöntemler kamuoyuyla paylaşılmıştır. Hastalığın ilk ortaya çıktığı zaman hukuk alanında yarattığı mücbir sebep etkisi, hastalık hakkında bilinenler ve buna bağlı olarak korunma yöntemlerine iliş̧in bilgi arttıkça ortadan kalkmaktadır ${ }^{81}$. Bu görüşten hareketle, Covid-19 hastalığının Türkiye'de görülmesinden önceki seyri ve bu süreçte hastalıktan korunmakla ilgili öğrenilen bilgiler dikkate alındığında kanımızca Covid-19'un iş kazaları bakımından mücbir sebep olarak değerlendirilmesi mümkün değildir. Hastalığın Türkiye'ye ulaşmasına kadar geçen süreçte bulaşma ve hastalıktan korunma yollarına dair bilimsel bilgi gelişmiştir; dolayısıyla işverenin hastalık ülkede tespit edildiği andan itibaren işçiyi gözetme borcunu yerine getirmek için söz konusu yöntemleri uygulama imkânı vardır. İşverenin hastalığın mücbir sebep olduğunu ileri sürerek sorumluluktan kurtulması mümkün olmamalıdır.

Son olarak eklenmelidir ki, Covid-19 salgını mücbir sebep teşkil edecek ağırlıkta mutlak bir kaçınılmazlık teşkil etmese de hastalığın hala tam olarak önlenememesi ve korunma önlemlerine rağmen bulaşma riskinin tamamen ortadan kaldırılamaması sebebiyle işçinin Covid-19 hastalığına yakalanmasında kaçınılmazlık payı olabilir. Yargıtay'a göre "Kaçınılmazlık, hukuksal ve teknik anlamda, fennen önlenmesi mümkün bulunmayan başka bir anlatımla, işverence mevzuatın öngördüğü tüm önlemlerin alınmış olduğu koşullarda dahi önlenmesi mümkün bulunmayan durum ve sonuçları ifade eder. "Yüksek mahkeme olayın tamamen kaçınılmazlık sonucunda meydana gelmesi halinde, tazminat hesabında tarafların sosyal ve ekonomik durumlarını dikkate alarak, tarafların kaçınılmazlığa yarı yarıya katlanması yerine işverene yarıdan biraz daha fazla sorumluluk yüklemektedir ${ }^{82}$. Yine işveren veya işçinin kusurunun yanında kaçınılmazlığın da etkisinin olduğu hallerde de işverene biraz daha fazla sorumluluk yüklenerek tarafların kusur oranı ve hakkaniyet dikkate alınarak zarar paylaştırılmaktadır ${ }^{83}$. Dolayısıyla işçinin, işiyle illiyet bağı içerisinde Covid-19 hastalığına yakalanması durumunda kaçınılmazlığın da rol oynaması halinde, Yargıtay'ın mevcut içtihadından hareketle tazminat hesabında kaçınılmazlık payının işverene daha fazla sorumluluk yüklenerek taraflar arasında paylaştırılması beklenebilir.

\section{SONUÇ}

Çalışanların Covid-19 hastalığına yakalarak sürekli işgöremez veya malul olmaları ya da yaşamlarını kaybetmeleri durumunda hastalığa hangi koşullarda maruz kalındığı ve hukuken nasıl nitelendiği, sigortalıların ve ölümleri halinde geride kalanların haklarını önemli ölçüde etkilemektedir. Hastalığın, yasada yer alan koşullarda bulaşması halinde iş kazası veya meslek hastalığ nitelendirilmesi mümkündür. Ne var ki, Covid-19'un bir salgın niteliğinde olması ve solunum yoluyla bulaşması ispat yönünden güçlükleri beraberinde getirmektedir. Söz konusu ispat güçlügü, sigortalıların aleyhine sonuç verecek ş̧ekilde etki doğurmamalıdır. Sosyal sigortalar açısından, hastalığın niteliği belirlenirken sosyal devlet ilkesi ve SSGSSK'nin iş kazası bakımından sosyal koruma çerçevesini mümkün olduğunca genişleten ruhu dikkate alınmalıdır. Bu bağlamda, Sağlık Bakanlığı'nın 18.12.2020 tarihli yazısı çerçevesinde sağlık çalışanlarının Covid-19 hastalığına yakalanmalarının, meslek hastalığı olarak bildirimini kolaylaştıran düzenleme olumlu bir adımdır. Ancak, yazı, sağ lık kuruluşlarında çalışan herkesi kapsamadığı gibi, hastalığın işle olan illiyet bağının kurulmasını güçleştirecek yönler içermektedir. Sağlık kurum ve kuruluşlarında çalışanlar açısından uygun çözüm, hastalığın meslek hastalıkları listesine alınması olacaktır. Diğer çalışanlar bakımından, yasada yer alan koşullarda hastalığa maruz kalındığının tespiti halinde, hastalığın iş kazası olarak nitelendirilmesi hukuken mümkündür. Bu çalışanlar bakımından, hastalığın işyerinde veya işle ilgili süreçlerde bulaştı̆ının mutlak bir biçimde ispatının aranması, yasanın koruyucu çerçevesini daraltacaktır. $\mathrm{Bu}$ nedenle, sigortalının hastalığa işyerinde yakalanmasının özel hayatında yakalanmasına nazaran daha olası olduğu hallerde, sigortalı ilgili edimlerden yararlandırılmalıdır. Bireysel iş ilişkisinde Covid-19'a yakalanan işçinin tazminat talebinin doğabilmesi için, işverenin işçinin hastalanmasında kusuru aranır. İşverenin gelişen bilim ve teknolojinin elverdiği önlemleri almaması işverene kusur olarak atfedilebilir. İş̧⿻inin hastalığa işiyle bağlantılı olarak yakalandığının tespitinde filyasyon raporları etkili olacaktır; ancak bunlara mutlak bir değer verilemez. Covid-19'un

\footnotetext{
${ }^{81}$ AKIN, Covid-19, s.32; ARSLAN DURMUŞ, s.382.

82 Yarg. 21. HD. 10.4.2017, 2016/115, 2017/2948, (www.kazanci.com.tr) . Örneğin söz konusu kararda “Yargıtay'ın yerleşik uygulaması da bu yöndedir. Somut olayda iş kazasının gerçekleşmesinde \% 100 oranında kaçınılmazlığın etkili olduğu tesbit edildiğine göre yukarda söz edilen ilkeler göz önünde bulundurularak, özellikle nimet ve külfet dengesinin sağlanması açısından kaçınılmazlı̆̆ın \% 60'ı davalı işverene yüklenmek suretiyle davalı işverenin sorumluluğu belirlenmesi gerekirken, davalının kaçınılmazlığın \%50'si oranında sorumluluğunu doğuracak şekilde ve olayda uygulanma ihtimali bulunmayan hakkaniyet indirimine yönelik hukuki düzenlemeye atıfla, davalı işverenin sorumluluğu hafifletilmek suretiyle yazıl şsekilde karar verilmesi usul ve yasaya aykırıdır. " ifadelerine yer verilmiştir.

${ }^{83}$ SÜZEK, s.418.
} 
salgın niteliğinde olması da uygun illiyet bağını kesecek nitelikte değildir. Gerekli önlemleri almaksızın çalıştırdığı işçilerin hastalığa yakalanmaları durumunda işverenin tazminat sorumluluğu doğabilir.

KAYNAKÇA

AKIN, Levent: "Covid-19'un İș İlişsilerine Olası Etkileri”, Çimento İșveren Dergisi, 34(3), Mayıs 2020, s.1671. (Covid-19)

AKIN, Levent: İş Kazasından Doğan Maddi Tazminat, Yetkin Yayınları, Ankara 2001.

ARSLAN DURMUŞ, Seda: “COVID-19'un İş Kazası ve Meslek Hastalığı Bakımından Değerlendirilmesi”, İstanbul Hukuk Mecmuas1, 78(2), 2020, s.363-393.

ATEŞ, Zehra Gizem: "Covid-19'un İșverenin İș Sağlığı ve Güvenliği Konusunda Alması Gereken Önlemlere Etkisi”, İstanbul Ticaret Üniversitesi Sosyal Bilimler Dergisi Covid-19 Hukuk Özel Sayıs1, 19(38), s.161-179.

BAYCIK, Gaye: "Çalışanların İş Sağlığı ve Güvenliğine İlişkin Haklarında Yeni İş Kazası ve Meslek Hastalı̆̆ Nedeniyle İşverenin Sorumluluğu Düzenlemeler”, Ankara Barosu Dergisi, 2013/3, s.104170.

ÇELIK, Nuri/CANiKLIOĞLU, Nurşen/CANBOLAT, Talat: İş Hukuku Dersleri, 33. Bası, Beta Yayınları, İstanbul 2020.

ERDOĞAN, Çağla: İşveren ve İşveren Vekilinin İş Kazasından Doğan Cezai Sorumluluğu, Yetkin Yayınları, Ankara 2016.

EREN, Fikret: Borçlar Hukuku ve İş Hukuku Açısından İşverenin İş Kazası ve Meslek Hastalığından Doğan Sorumluluğu, AÜHF Yayınları, Ankara 1974. (İş Kazası)

EREN, Fikret: Sorumluluk Hukuku Açısından Uygun İlliyet Bağı Teorisi, AÜHF Yayınları, Ankara 1975. (İlliyet Bağı)

FRANGIÉ-MOUKANAS, Joumana/POTIER, Corinne: Coronavirus : un risque professionnel ?, Semaine Sociale Lamy, No. 1909, 25.5.2020. (https://www.lamyline.fr)

GÜZEL, Ali/OKUR, Ali Rıza/CANiKLIOĞLU, Nurşen: Sosyal Güvenlik Hukuku, 18. Bası, Beta Yayınları, İstanbul 2020.

İZMİRLİĞLU, Ayça: "İşverenin Sağlık Gözetimi Sağlama Yükümlülüğüne COVID-19 Salgını Bağlamında Genel Bir Bakış", İstanbul Hukuk Mecmuası, 78(2), 2020, s.455-483.

LU, J./GU, J./LI K. ve diğerleri: COVID-19 Outbreak Associated with Air Conditioning in Restaurant, Guangzhou, China, 2020, Emerging Infectious Diseases, 2020, 26(7), s.1628-1631.

NARTER, Sami/ŞİMŞEK, Cebrail: "Sağglık Çalışanları İçin Covid-19 Hastalığı İş Kazası Veya Meslek Hastalığı Mıdır?", Karatahta İş Yazıları Dergisi, (16) 2020, s.139-170.

ÖZDEMIR, Erdem: İş Sağlığı ve Güvenliği Hukuku, Vedat Kitapçılık İstanbul 2014.

SERATLI, Gaye Burcu: İş Kazasından Doğan Destekten Yoksun Kalma Tazminatı, Yetkin yayınları, Ankara 2003.

SÖZER, Ali Nazım: "Sosyal Sigortaların Genel Hükümleri ve Türleri”, Yargıtay'ın İş Hukuku ve Sosyal Güvenlik Hukuku Kararlarının Değerlendirilmesi Semineri 2014, Oniki Levha Yayınları, İstanbul 2017, s.535-585.

SÖZER, Ali Nazım: Türk Sosyal Sigortalar Hukuku, 2. Bası, Beta Yayınları, İstanbul 2015.

SÜMER, Haluk Hadi: İş Sağlığı ve Güvenliği Hukuku, 3. Bası, Seçkin Yayınları, Ankara 2019.

SÜZEK, Sarper: İș Güvenliği Hukuku, Savai Kitabevi, Ankara 1985. (İş Güvenliği)

SÜZEK, Sarper: İş Hukuku, 19. Bası, Beta Yayınları, İstanbul 2020.

ŞAHIN EMIR, Asiye: İşçinin Yakalandığı Bulaşıcı Hastalığın 5510 Sayılı Kanun Olup Olmadığının Değerlendirilmesi - Domuz Gribi (H1N1) ve Koronavirüs (Covid-19) Özelinde Bir Değerlendirme-, Legal İSGHD 17(66), s.547-592.

TUNCAY, Can/EKMEKÇİ Ömer: Sosyal Güvenlik Hukuku Dersleri, 20. Bası, Beta Yayınları, İstanbul 2019.

ULUSAN, İlhan: İşverenin İşçiyi Gözetme Borcu ve Bundan Doğan Sorumluluğu, Kazancı Hukuk Yayınları, İstanbul 1990.

YÜREKLİ, Sabahattin: "Çalışma Hayatında Koronavirüs (Covid-19) Salgınının Etkileri, İstanbul Ticaret Üniversitesi Sosyal Bilimler Dergisi Covid-19 Hukuk Özel Sayısı”, 19(38), s.34-61. 